\author{
Jacek Maciejewski \\ (Kazimierz Wielki University, Bydgoszcz, Poland) \\ https://orcid.org/0000-0003-0505-975X \\ E-mail: jmac@ukw.edu.pl
}

\title{
Biskupi polscy na wojnach monarchów w XIII-XIV wieku
}

\author{
Polish Bishops at the Wars of Monarchs in 13th-14th Century
}

\begin{abstract}
The obligation to serve a ruler directly at war existed also in Poland until the first part of 13th century, however, with the passage of time it underwent significant changes and became subject to constant negotiations, which was mostly influenced by current relations between local Church and secular power. The collapse of central power then, with simultaneous increase of papal influence in Poland, led to the emancipation of the Polish Church and it resulted, among others, in the lack of bishops' participation in the military affairs of Piast princes. Although there were clear tendencies to change this attitude during the unification period, this did not result in the militarization of the episcopate in the likeness of neighboring countries. The bishops were re-included in the sphere of state activity, but neither the rulers, it seems, insisted on the personal military involvement of the hierarchs, nor did the latter voluntarily show any greater interest in warfare, which could have been a consequence of changing cultural norms and social expectations among the elites of the late medieval Kingdom of Poland.
\end{abstract}

\begin{tabular}{|l|l|l|l|}
\hline PUBLICATION INFO \\
\hline
\end{tabular}


Key words: bishops and war, warrior bishop, canon law, clerical armsbearing, episcopal warfare, Piast Poland

\section{STRESZCZENIE}

Obowiązek służenia władcy bezpośrednio na wojnie istniał także w Polsce średniowiecznej, ale w XIII i XIV w. podlegał znaczącym przemianom i był ciągle przedmiotem negocjacji, na które największy wpływ miały aktualne stosunki lokalnego Kościoła z władcą. Załamanie się władzy centralnej w pierwszych dziesięcioleciach XIII w., przy jednoczesnym wzroście wpływów papieskich doprowadziło do emancypacji kościoła w stosunku do władzy świeckiej, co zaowocowało także nieuczestniczeniem biskupów w wyprawach zbrojnych książąt. W okresie zjednoczeniowym pojawiły się co prawda wyraźne tendencje do zmiany tego nastawienia, ale nie zaowocowało to militaryzacją episkopatu na podobieństwo krajów sąsiednich. Biskupi zostali ponownie włączani w sferę działalności państwowej, ale ani władcy, jak się zdaje, nie nalegali na osobiste zaangażowanie zbrojne hierarchów, ani ci drudzy z własnej woli nie wykazywali większego zainteresowania rzemiosłem wojennym, co mogło być konsekwencją zmiany norm kulturowych i oczekiwań społecznych wśród elit późnośredniowiecznego Królestwa Polskiego.

Słowa kluczowe: biskupi a wojna, prawo kanoniczne, posługiwanie się bronią przez duchownych, prowadzenie wojny przez biskupa, Polska piastowska

Związki średniowiecznego episkopatu Kościoła katolickiego ze sferą militarną były bardzo bliskie i przejawiały się w różnorodny sposób, obejmując zarówno liczne kwestie związane ze wzmacnianiem przez biskupów potencjału wojskowego panujących, jak i osobiste uczestnictwo hierarchów kościelnych w zmaganiach zbrojnych ${ }^{1}$. W tym drugim przypadku chodzi o udział prałatów zarówno w naradach wojennych, związanych z wojną misjach dyplomatycznych czy o przewodniczenie rytuałom religijnym, przez które starano się zaskarbić przychylność niebios dla zwycięstwa i podnieść morale armii przed walka, jak i o osobisty udział

1 Problematyka ta od dawna budzi zainteresowanie badaczy z różnych krajów. Z nowszych opracowań traktujących w całości lub częściowo o tych sprawach zob. przede wszystkim: H. Hoffmann, Der König und seine Bischöfe in Frankreich und im Deutschen Reich 936-1060, w: Bischof Burchard von Worms 1000-1025, red. W. Hartmann, Mainz 2000, s. 79-127; D.S. Bachrach, Religion and the Conduct of War, c.300-c.1215, Woodbridge 2003; M. Sot, Des érếues á la guerre (VIIIe-XIII ciècle), w: Guerre et société (IXe-XIIIe siècle), red. J.-C. Chenyet, D. Barthelemy, Paris 2011, s. 103-112; A. Arranz Guzmán, Cuando el clérigo va a la Guerra: algunos ejemplos de obispos "peleadores", w: Guerra y paz en la Edad Media, red. eadem, M. del Pilar Rábade Obradó, Ó. Villarroel Gonzáles, Madrid 2013, s. 275-308; L.G. Duggan, Armsbearing and the Clergy in the History and Canon Law of Western Christianity, Woodbridge 2013; C.M. Nakashian, Warrior Churchmen of Medieval England 1000-1250. Theory and Reality, Woodbridge 2016; D. Gerrard, The Church at War: The Military Activities of Bishops, Abbots, and Other Clergy in England, c. 900-1200, Abingdon-New York 2016; Between Sword and Prayer. Warfare and Medieval Clergy in Cultural Perspective, red. R. Kotecki, J. Maciejewski, J.S. Ott, Leiden-Boston 2018. 
biskupów w kampaniach zbrojnych czy nawet bitwach w charakterze różnego szczebla dowódców, a nawet jako rycerzy walczących z bronią w ręku. To właśnie ta druga grupa zagadnień będzie nas tu szczególnie interesowała w odniesieniu do hierarchów polskich XIII i XIV stulecia. Celem niniejszego opracowania jest bowiem analiza zmian, które zachodziły $\mathrm{w}$ domenie piastowskiej $\mathrm{w}$ okresie rozbicia dzielnicowego oraz w zjednoczonym państwie rządzonym przez dwóch ostatnich królów piastowskich, w odniesieniu do kwestii związanych z udziałem biskupów polskich $\mathrm{w}$ wyprawach zbrojnych monarchów oraz prowadzenia przez ordynariuszy wojny na podstawie monarszego mandatu. Niestety, problemy te były niemal zupełnie pomijane przez ówczesnych historiografów polskich, co samo w sobie jest bardzo interesujące i prowokuje liczne pytania o źródła takiego podejścia do tematu. Pozbawia nas to jednak możliwości bliższego przyjrzenia się, jak elity ziem piastowskich radziły sobie z problemem bezpośredniego uczestnictwa duchowieństwa W wojnie. W tej sytuacji szczególnego znaczenia nabierają różne, często rozproszone i przypadkowe informacje, zachowane w źródłach aktowych, między którymi poczesne miejsce zajmują akta procesów kanonicznych wytoczonych biskupowi krakowskiemu Janowi Muskacie oraz XIV-wiecznych procesów polsko-krzyżackich ${ }^{2}$. Przydatne w związku z tym okazało się także zastosowanie metody komparatystycznej, która pozwala na lepsze zrozumienie polskiej podstawy źródłowej, a także metody retrogresywnej, gdyż niektóre zjawiska są lepiej oświetlone przez źródła odnoszące się dopiero do panowania Jagiellonów. Przy wykorzystaniu obu metod niezbędna jest, rzecz jasna, ostrożność i dążenie do należytej kontekstualizacji wykorzystanych przekazów.

Prawo kościelne, co ciekawe, nie wypowiadało się o tych sprawach tak jednoznacznie, jak można by oczekiwać. W Dekrecie Gracjana w zasadzie zakazano biskupom chodzić na wojnę, czy to z własnej inicjatywy, czy też z rozkazu księcia ${ }^{3}$. Ale to właśnie tam wskazano, że należy dokonać rozróżnienia między duchownymi, którzy są zobowiązani, by służyć panom świeckim, i tymi, którzy wolni są od takich zobowiązań. Natomiast całkowicie i jednoznacznie zabraniano duchownym osobiście

2 Monumenta Poloniae Vaticana [dalej: MPV], t. 3, wyd. J. Ptaśnik, Cracoviae 1914, nr 111 i 121; Lites ac res gestae inter Polonos Ordinemque Cruciferorum, t. 1, red. I. Zakrzewski, Posnaniae 1890 [dalej: Lites (1339)]; Lites ac res gestae inter Polonos Ordinemque Cruciferorum, t. 1, Causa Junivladislaviae et Brestiae-Cuiaviae anno 1320-1321 acta, red. H. Chłopocka, WrocławWarszawa-Kraków 1970 [dalej: Lites (1320)].

3 Corpus iuris canonici, t. 1, Decretum magistri Gratiani, wyd. E. Friedberg, wyd. 2, Graz 1959, p. 2, c. 23, q. 8, kol. 953-965; M. Sot, op. cit., s. 105; S. Schild, Bishops in the Service of the Staufen and the Plantagenets, w: Staufen and Plantagenets. The Empires in Comparision, red. A. Plassmann, D. Büschken, Bonn 2018, s. 139-142. 
walczyć i przelewać czyjąś krew ${ }^{4}$. W ciągu kolejnych dwóch stuleci trwała intensywna dyskusja o obowiązku militarnym biskupów względem władcy. Większość komentatorów ignorowała twierdzenie Gracjana, że biskup może iść na wojnę tylko po uprzednim uzyskaniu pozwolenia papieskiego, czego domagał się jeszcze autor anonimowego komentarza dzieła Gracjana z ok. 1170 r. pt. Summa Parisiensis, a tylko już dora-

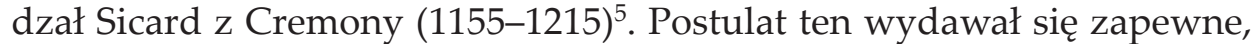
szczególnie poza Italia, niemożliwy do spełnienia ${ }^{6}$. Duże znaczenie miały w tym kontekście poglądy papieża Innocentego IV (1243-1254), który twierdził, iż biskupi, którzy mają władzę terytorialna, mogą posłużyć się wojną aby władzę tę chronić. Nie mieli jednak prawa prowadzić jej osobiście, mogli natomiast, a nawet byli zobligowani ze względu na posiadanie dóbr ziemskich, służyć władzy królewskiej w sferze militarnej i w ten sposób „oddawać cesarzowi co cesarskie”, zgodnie z prawem używając żołnierzy, których mieli pod swoją komendą. W zasadzie też, podobnie jak innym duchownym, nie było im wolno walczyć osobiście, ale warto pamiętać, iż duchowny miał prawo, szczególnie od czasów papieża Aleksandra III (1159-1181), do obrony własnej i nawet zranienia lub zabicia napastnika w obronie swego życia, bez obawy zaciągnięcia wadliwości (irregularitas), co pozostawiało już bardzo dużą swobodę dla interpretacji zdarzeń?

Zagadnienia związane z osobistym udziałem biskupów polskich $\mathrm{w}$ wojnach nie były dotąd tematem osobnego opracowania w odniesieniu do interesującego nas okresu. Odnotować wszakże należy, iż badacze poświęcali już sporo uwagi analizie niektórych kwestii szczegółowych, które pokazywały militarne aspekty posługi biskupiej w średniowiecznej Polsce ${ }^{8}$. Ponadto dość dobrze, w zakresie, w jakim pozwalały na to źródła,

4 R.L. Benson, The Obligations of Bishops with "Regalia": Canonistic Views from Gratian to the Early Fifteenth Century, w: Proceedings of the Second International Congress of Medieval Canon Law, red. S. Kuttner, J.J. Ryan, Città del Vaticano 1965, s. 130; F.H. Russell, The Just War in the Middle Ages, Cambridge 1975, s. 105, 109; L.G. Duggan, op. cit., s. 128-130.

5 F.M. Russell, op. cit., s. 109-110.

6 K.V. Jensen, Bishops on Crusade, w: Dominus Episcopus. Medieval Bishops Between Diocese and Court, red. A.J. Lappin, E. Balzamo, Stockholm 2018, s. 85.

$7 \quad$ L.G. Duggan, op. cit., s. 142; K.C. Lincoln, Beating Swords into Croziers: Warrior Bishops in the Kingdom of Castile, c. 1158-1214, "Journal of Medieval History" 2017, 44, 1, s. 1.

8 M. Friedberg, Klientela świecka biskupa krakowskiego w w. XII-XIV. Ze studiów nad organizacja społeczeństwa w Polsce średniowiecznej, Kraków 1938, szczeg. s. 174-177, 196-202; A.F. Grabski, Polska sztuka wojenna w okresie wczesnofeudalnym, Warszawa 1959, s. 43; J. Dowiat, Kilka uwag o stownictwie Galla Anonima w zwiazku z zagadnieniem organizacji sił zbrojnych za Bolesława Krzywoustego, „Kwartalnik Historyczny” 1959, 66, 1, s. 47; L. Wojciechowski, Wyprawy łupieskie w słowiańszczyźnie zachodniej w X-XII w., „Roczniki Humanistyczne” 
problemy te rozpoznano $\mathrm{w}$ odniesieniu do XII stulecia, $\mathrm{w}$ dużym stopniu dzięki zastosowaniu metody porównawczej ${ }^{9}$. Badania potwierdziły przekonanie, że w XII-wiecznej Polsce biskupi brali udział w książęcych ekspedycjach zbrojnych, spełniając w armii posługi duszpasterskie w stosunku do swoich diecezjan i organizując oracje o zwycięstwo władcy

1983, 31, 2, s. 68; K. Mosingiewicz, Choragwie rodowe i ich dowódcy w bitwie pod Grunwaldem, w: Prace z dziejów państwa i zakonu krzyżackiego, red. A. Czacharowski, Toruń 1984, s. 118120; M. Bogacki, Przemiany w wojskowości polskiej od połowy X wieku do 1138 roku. Kształt i organizacja armii, Toruń 2007, s. 234-235; S. Szybkowski, Duchowni "panowie choragiewni” podczas letniej wyprawy na Prusy w 1410 r., w: Kościót i społeczeństwo. Studia nad obiegiem informacji $i$ konfliktami zbrojnymi w dawnych i nowych wiekach, red. J. Grabowski, Warszawa 2012, s. 209-225. O kwestiach duszpasterskich rozprawiali natomiast: E. Nowak, Rys dziejów duszpasterstwa wojskowego w Polsce 968-1831, Warszawa 1932, s. 6-8; J. Manthey, Średniowieczne duszpasterstwo wojskowe, „Duszpasterz Polski Zagranicą” 1958, 9, 3, s. 259-277; J. Sójka, Posługi duszpasterskie przy wojskach polskich w wiekach średnich, w: Studia z dziejów feudalizmu, red. S.M. Zajączkowski, Łódź 1994, s. 93-105; J. Ptak, Duszpasterstwo rycerstwa polskiego w epoce Piastów i Jagiellonów, w: Historia duszpasterstwa wojskowego na ziemiach polskich, red. J. Ziółek, Lublin 2004, s. 83-108; idem, Zanim wyruszyli na wroga... Religijne przygotowanie do walki zbrojnej w średniowiecznej Polsce, „Teka Komisji Historycznej. Oddział Lubelski PAN" 2014, 11, s. 20-45.

9 J. Banaszkiewicz, Potrójne zwycięstwo Mazowszan nad Pomorzanami - Gall II, 49 - czyli historyk między "rzeczywistościa prawdziwa" a schematem porządkującym, w: Kultura średniowieczna i staropolska. Studia ofiarowane Aleksandrowi Gieysztorowi w pięćdziesiąta rocznice pracy naukowej, red. D. Gawinowa et al., Warszawa 1991, s. 305-313; M. Tomaszek, Modlitwa i łzy bronia biskupa. Pasterze polskiego Kościoła a walka orężna w ujęciu Wincentego Kadłubka, „Roczniki Historyczne" 2005, 71, s. 121-136; M.R. Pauk, E. Wółkiewicz, "Ministri enim altaris ministri curie facti sunt”. Ottońsko-salicki "system" Kościoła Rzeszy i jego oddziaływanie w Europie Środkowej XI-XII wieku, w: Kościót w monarchiach Przemyślidów i Piastów, red. J. Dobosz, Poznań 2009, s. 116-119; R. Kotecki, Ordynariusz płocki Szymon w Gallowej narracji o bitwie Mazowszan z Pomorzanami, w: Ecclesia et bellum. Kościót wobec wojny i zaangażowania militarnego duchowieństwa w wiekach średnich, red. R. Kotecki, J. Maciejewski, Bydgoszcz 2016, s. 141-167; idem, With the Sword of Prayer, or How Medieval Bishop Should Fight, "Quaestiones Medii Aevi Novae” 2016, 21, s. 341-369; idem, Aleksander z Malonne - „persona mixta”. Wojowniczy biskup na krańcach chrześcijańskiego świata i jego kronikarski portret, "Studia Źródłoznawcze" 2017, 55, s. 51-78; idem, Lions and Lambs, Wolves and Pastors of the Flock: Portraying Military Activity of Bishops in Twelfth-Century Poland, w: Between, s. 303-340; J. Maciejewski, Biskup krakowski Petka a bitwa nad Mozgawa w 1195 roku, „Kwartalnik Historyczny” 2018, 124, 3, s. 411-438; idem, A Bishop Defends His City or Master Vincentius's Troubles with the Military Activity of His Superior, w: Between, s. 341-368; idem, Memory of Warrior Bishops of Płock in the Writings of Jan Dtugosz, w: Christianity and War in Medieval East Central Europe and Scandinavia, red. R. Kotecki, C. Selch Jensen, S. Bennett, Leeds 2021, s. 75-95; R. Kotecki, J. Maciejewski, Writing Episcopal Courage in Twelfth-Century Poland: Gallus Anonymous and Master Vincentius, w: In the Hands of God's Servants' III: The Power of the Bishop and the Problem of Personality, red. P.R. Coss et al., Turnhout 2020, s. 35-61. 
i jego ludzi. Wykazano ponadto, iż kontakty episkopatu polskiego ze sferą wojny obejmowały także przywództwo w czasie wypraw wojennych organizowanych bądź w zastępstwie książąt, bądź w sytuacji nagłego zagrożenia, w tym także z własnej inicjatywy. A zatem w pewnych warunkach kompetencje militarne hierarchów kościelnych pozwalały im posługiwać się osobiście bronią doczesną $\mathrm{w}$ postaci rycerstwa. Brak natomiast jednoznacznego potwierdzenia, by polscy prałaci chwytali za broń i brali udział w walce, choć pewne przesłanki ku takiemu przekonaniu istnieją.

W każdym razie można dla okresu do początku XIII w. zaobserwować, iż normy kulturowe oraz oczekiwania społeczne sprzyjały wojowniczym biskupom, przy czym akceptacja dla ich militarnego zaangażowania była szczególnie widoczna w odniesieniu do terenów zagrożonych przez najazdy pogan ${ }^{10}$. Było to zresztą zjawisko spotykane $\mathrm{w}$ całym świecie chrześcijańskim, w krajach położonych peryferyjnie i narażonych na liczne konflikty zbrojne $\mathrm{z}$ niechrześcijańskimi sąsiadami ${ }^{11}$.

Przedstawione wyżej wnioski sformułowane na podstawie źródeł miejscowych znajdują potwierdzenie $\mathrm{w}$ obcych relacjach dotyczących Polski i krajów ościennych. Znamienna jest pełna oburzenia opinia wyrażona $\mathrm{w}$ połowie XII w. w otoczeniu księcia Izjasława II, iż biskupi łacińscy „chodzą na wojnę"12, która może dotyczyć zarówno pobliskiej Polski, jak i bliskich jej kulturowo i geograficznie Węgier ${ }^{13}$. W przypadku

10 R. Kotecki, Aleksander, szczeg. s. 71, 74-76; idem, Lions, s. 329; J. Maciejewski, Memory, s. 75-95.

11 G. Bührer-Thiery, Des érêques sur la frontiére. Christianisation et sociétés de frontiére sur les marches du monde germanique aux Xe-XIe siècle, "Questiones Maedii Aevii Novae" 2011, 16, s. 61-80; S. Hamilton, Church and People in the Medieval West, 900-1200, London 2013, s. 91, D. Gerrard, op. cit., s. 136-50; K.C. Lincoln, op. cit., s. 1-21.

12 J.S. Gajek, Teodozjusz Grek i jego "Słowo o wierze chrześcijańskiej i łacińskiej”, w: Teologia i kultura duchowa starej Rusi, red. W. Hryniewicz, J.S. Gajek, Lublin 1993, s. 245.

13 Krytyka taka mogła pojawić się w związku z niewątpliwymi wpływami kulturowymi płynącymi z obydwu tych krajów i osobistymi kontaktami ich elit, co zaważyło na przykład na funkcjonowaniu duchowieństwa w otoczeniu władców Rusi Halicko-Wołyńskiej. Przykładem może być metropolita kijowski Cyryl (1247-1281), który zawdzięczał swój urząd między innymi pełnieniu funkcji kancelaryjnych przy Danielu Halickim i angażowaniu się w misje wojskowo-polityczne w imieniu tego władcy. Przypomina to aktywność militarną takich hierarchów jak biskup krakowski Pełka, arcybiskup gnieźnieński Wincenty z Niałka czy też arcybiskup Kolocsy, Ugrin. Pamiętać jednak należy, że Cyryl, choć autor kroniki gmatwa bardzo chronologię zdarzeń, pełnił urząd pieczętnika i angażował się w sprawy militarne i dyplomatyczne Romanowiczów tylko w okresie przed formalnym objęciem metropolii kijowskiej, Kronika Halicko-Wołyńska (Kronika Romanowiczów), wyd. D. Dąbrowski, A. Jusupović, Monumenta Poloniae Historica [dalej: MPH], Nova series, t. 16, Kraków-Warszawa 2017, s. 247-249, 251, 257-258, 297-298; D. Dąbrowski, Król Rusi Daniel Romanowicz. O ruskiej rodzinie książęcej, społeczeństwie i kulturze w XIII w., Kraków 
tych ostatnich źródła potwierdzają bowiem udział biskupów w wojnach, nawet poza granicami kraju, już w odniesieniu do XI-XII w. ${ }^{14}$ Nie inaczej przedstawia się sytuacja w przypadku Czech i krajów skandynawskich, gdzie udział biskupów w wyprawach zbrojnych monarchów również był powszechnym zjawiskiem ${ }^{15}$. Na całym tym obszarze, od Węgier po Półwysep Skandynawski, biskupi byli zobowiązani do udzielania władcom na ich życzenie pomocy zbrojnej. Trudno jest przy tym orzec, w jakim zakresie i od którego momentu w poszczególnych krajach odwoływano się do koncepcji regaliów, która właściwie dopiero się kształtowała ${ }^{16}$. Ważniejsza w tym względzie była adaptacja na tych terenach, w mniejszym lub większym zakresie za pośrednictwem Rzeszy, koncepcji

2016, s. 324-326; A. Jusupović, Pieczętnik a tysięcznik. Kariera Cyryla pieczętnika, późniejszego metropolity w XIII-wiecznej Rusi, „Przegląd Wschodni” 2017, 14, 3, s. 621-624, 629-632.

14 Annales Posonienses, Scriptores Rerum Hungaricarum, t. 1, wyd. E. Szentpétery, Budapestini 1937, s. 126; Powieść minionych lat, tłum. F. Sielicki, Wrocław-Warszawa-Kraków 1999, s. 211-212; Latopis kijowski, cz. 1, tłum. E. Goranin, Wrocław 1995, s. 93, 115; Cosmae Pragensis Chronica Boemorum, wyd. B. Bretholz, Monumenta Germaniae Historica, Scriptores Rerum Germanicarum, Nova series, t. 2, Berolini 1923, s. 216. Pozycja biskupów w państwie Arpadów w XI w. wydaje się analogiczna do obrazu nakreślonego przez Galla odnośnie do relacji Bolesława Chrobrego z biskupami; por. E. Nemerkényi, The Representation of the Bishops in the Institutio of King Stephen of Hungary, "Acta Classica Universitatis Scientiarum Debrecenensis" 2001, 37, s. 83.

15 O udziale biskupa praskiego w wyprawie na Wielkopolskę w roku 1038/39 i o wojennym zaangażowaniu w roku 1105 jednego z jego następców Hermana, zob. Cosmae Pragensis, s. 84-90, 180. W XII stuleciu biskup Daniel był uczestnikiem wypraw zbrojnych Fryderyka I do Italii oraz Polski przynajmniej trzykrotnie, raz zaś był obecny w miejscu koncentracji oddziałów, J.-P. Stöckel, Reichbischöfe und Reichheerfahrt unter Friedrich I. Barbarossa, w: Keiser Friedrich Barbarossa. Landesaubau - Aspekte seiner Politik - Wirkung, red. E. Engel, B. Töpfel, Weimar 1994, s. 64-65. O krucjatowych wyprawach biskupów czeskich do Palestyny, Prus oraz na Połabie, J. Žemlička, Jindřich Zdík, Biskup, dyplomat, a organizator, w: Jindřich Zdík (1126-1150). Olomoucký biskup uprostřed Evropy, red. J. Hrbáčová, Olomouc 2009, s. 13, 17, 25-26; D. von Güttner Sporzyński, Poland, Holy War, and the Piast Monarchy (1100-1230), Turnhout 2014, s. 113-114; S. Górski, Biskupi i krzyże. Tak zwany epizod szczeciński krucjaty połabskiej (1147) w relacji Wincentego z Pragi, "Zapiski Historyczne" 2018, 83, 3, s. 9-10, 19-20. O Skandynawii zob. np.: S. Bagge, From Viking Stronghold to Christian Kingdom: State Formation in Norway, c. 900-1350, Copenhagen 2010, s. 231; A. Perron, Saxo Grammaticus's Heroic Chastity: A Model of Clerical Celibacy and Masculinity in Medieval Scandinavia, w: Negotiating Clerical Identities. Priests, Monks and Masculinity in the Middle Ages, red. J.D. Thibodeaux, Genders and sexualities in history, Basingstoke-New York 2010, s. 113-135; N. Lund, The Military Obligations of the Danish Church in the High Middle Ages, w: The Medieval Way of War: Studies in Medieval Military History in Honor of Bernard S. Bachrach, red. G.I. Halfond, Farnham-Burlington 2015, s. 295-307.

16 R.L. Benson, op. cit., s. 123-137; S. Gawlas, O kształt zjednoczonego królestwa. Niemieckie władztwo terytorialne a geneza społecznoustrojowej odrębności Polski, Warszawa 1996, s. 16-21. 
Kościoła monarszego ${ }^{17}$. Chodziłoby zatem o wypełnianie przez biskupów zobowiązań w stosunku do władcy i całej wspólnoty wiernych, które było kontynuacją stosunków panujących w imperium Karolingów i na obszarach stanowiących jego kontynuację, co miało także swoje głębsze uzasadnienie religijne ${ }^{18}$. Wattpliwe jednak, aby wymagania militarne kierowane przez monarchów pod adresem biskupów miały charakter systemowy, gdyż nowsze badania kwestionują taki model relacji monarchii i Kościoła nawet dla obszaru Rzeszy ${ }^{19}$.

Stan rzeczy nakreślony powyżej w odniesieniu do ziem polskich nie zmienił się jeszcze w pierwszych dziesięcioleciach XIII w. Z opartej zapewne częściowo o zaginione dziś źródła relacji Jana Długosza o bitwie pod Zawichostem w roku 1205 wynika, że armii książąt Leszka oraz Konrada Kazimierzowiców towarzyszyło przynajmniej dwóch biskupów, krakowski Pełka oraz płocki Wit. Mieli oni zostać wysłani na czele poselstwa, które bezskutecznie próbowało nakłonić księcia ruskiego do zgo$\mathrm{dy}^{20}$. Fragment dotyczący tej próby mediacji może być oczywiście tylko własną koncepcją kronikarza, który mógł się posłużyć w tym wypadku powszechnie znanym schematem ${ }^{21}$, bowiem biskupi zaliczali się $\mathrm{w}$ średniowieczu do grona szczególnie godnych zaufania mediatorów i także

17 M.R. Pauk, E. Wółkiewicz, op. cit., s. 133-136.

18 J.L. Nelson, Politics and Ritual in Early Medieval Europe, London 1986, s. 123-127; H. Hoffmann, op. cit., s. 109-126; R. Kotecki, Lions, p. 306; R. Kotecki, With, s. 350-360; C. Dennis, "De clericis qui pugnaverunt, aut pugnandi gratia armati fuerunt”. Bishop Geoffrey of Coutances (1048-1093) and Clerical Participation in the Battle of Hastings, w: Between, s. 88-116.

19 T. Reuter, The "Imperial Church System" of the Ottonian and Salian Rulers: A Reconsideration, „Journal of Ecclesiastical History" 1982, 33, 3, s. 347-374.

20 Joannis Dlugossi Annales seu cronicae incliti Regni Poloniae, lib. 1-12, ed. consilium, Varsaviae-Cracoviae 1964-2005 [dalej: Annales], lib. 6, s. 194.

21 J. Ptak, Co Jan Dtugosz mógł wiedzieć o bitwie rozegranej w 1205 roku pod Zawichostem?, w: Ecclesia - Cultura - Potestas. Studia z dziejów kultury i społeczeństwa, red. P. Kras et al., Kraków 2006, s. 684-686; G. Labuda, Zaginiona kronika w "Rocznikach" Jana Długosza, Poznań 1983, s. 35-36, a za nim L.P. Słupecki, Bitwa pod Zawichostem 19 czerwca 1205, w: Szkice zawichojskie, red. T. Dunin-Wąsowicz, S. Tabaczyński, Zawichost 1999, s. 96, sądzili, że ta relacja była oparta o informacje zaczerpnięte z zaginionej kroniki dominikanów krakowskich. Podobnie ostatnio L.P. Słupecki, Bitwa pod Zawichostem, niedziela 19 czerwca 1205, w: Zawichost we wczesnym średniowieczu, red. S. Tabaczyński, D. Wyczółkowski, współpr. D. Cyngot, Warszawa 2018, s. 57-62. Nawet jeśli tak nie było, to kanonik krakowski mógł korzystać z szeregu różnych, znacznie mniej obszernych, a dzisiaj nieznanych zbiorów zapisków czy not historiograficznych, zob. polemikę z tezami Labudy M. Zdanka, „Zaginiona kronika dominikańska" z XIII wieku. Próba nowego spojrzenia, w: Fontes et historia. Prace dedykowane Antoniemu Gąsiorowskiemu, red. T. Jurek, I. Skierska, Poznań 2007, s. 245-282. Zaś w konkretnym przypadku bitwy pod Zawichostem uwagi T. Nowakowskiego, Jan Długosz jako kronikarz dziejów piastowskiego Mazowsza (do początku XV w.), w: Dziedzictwo 
w tym charakterze, jak dowodzą źródła z terenu cesarstwa, towarzyszyli $\operatorname{armii}^{22}$. Jednakże udział $\mathrm{w}$ działaniach zbrojnych prowadzonych przez książąt lub samodzielnie $w$ ich imieniu, akurat w przypadku tych dwóch hierarchów, znajduje potwierdzenie także w kronice mistrza Wincente$\mathrm{go}^{23}$. Nieprzypadkowe wydaje się też i to, że obaj reprezentowali katedry położone w stolicach książęcych obu wspomnianych Piastów.

Podobne zadanie przypadło zresztą dwie dekady później w udziale arcybiskupowi Wincentemu z Niałka (1220-1232), który został posłany przez Władysława Laskonogiego, by negocjował pod oblężonym Lubuszem z landgrafem turyńskim Ludwikiem. Według niemieckiego rocznikarza metropolita gnieźnieński pokrzepiał na duchu obrońców i twardo, wręcz odważnie, negocjował z landgrafem ${ }^{24}$. Arcybiskup Wincenty został przy tym określony najwyższym książęcym kapelanem, który zajmował pierwsze miejsce wśród doradców księcia, co nie może dziwić w odniesieniu do osoby, która już przed swoją elekcją była związana z dworem książęcym ${ }^{25}$.

Z kolei czeskie źródło, a także informacje zaczerpnięte z ówczesnych dokumentów piastowskich nie pozostawiają wątpliwości, iż biskupi polscy uczestniczyli wraz ze swoimi książętami w wyprawach krzyżowych

ksiażat mazowieckich. Stan badań i postulaty badawcze, red. J. Grabowski, R. Mroczek, P. Mrozowski, Warszawa 2017, s. 46.

22 G. Althoff, Satisfaction. Peculiarities of the Amicable Settlement of Conflicts in the Middle Ages, w: Ordering Medieval Society: Perspectives on Intellectual and Practical Modes of Shaping Social Relations, red. B. Jussen, szczeg. s. 272-273.

23 Magistri Vincentii dicti Kadłubek Chronica Polonorum, wyd. M. Plezia, MPH, Nova series, t. 11, Kraków 1994, s. 161 (biskup Pełka organizuje obronę grodu krakowskiego przed buntownikami), 164 (Pełka interweniuje cudownie na rzecz Kazimierza powracającego do Krakowa), 166 (biskup płocki na wyprawie przeciwko poganom), 181-183 (biskup Pełka jako dowódca wojsk broniących Krakowa przed najazdem Mieszka III); S. Smolka, Mieszko Stary i jego wiek, Kraków 1881, tu cyt. wyd. Kraków 2009, s. 318; B. Kürbis, „Pollexianorum cervicosa feritas". Dzikość i barbarzyństwo w opinii Mistrza Wincentego, w: Stowianie w dziejach Europy, red. J. Ochmański, Poznań 1974, s. 135-136; J. Maciejewski, Biskup krakowski, s. 411-438; idem, A Bishop, s. 341-368.

24 Annales Reinhardsbrunnenses, wyd. F.X. Wegele, Thüringische Geschichtsquellen, t. 1, Jena 1854 , s. 180 .

25 J. Umiński, Arcybiskup Wincenty z Niałka, następca Henryka, zw. Kietliczem, w: Księga pamiątkowa ku czci Władysława Abrahama, Lwów 1931, s. 154, przyp. 2, który choć nie powołał się na powyżej cytowany rocznik niemiecki, to uważał, że Wincenty miał wojowniczą naturę i porównywał go do arcybiskupa Kolonii Rajnalda z Dassel. Uważa się powszechnie, że przed objęciem biskupstwa Wincenty był kanclerzem księcia Władysława Laskonogiego, S. Łaguna, Dwie elekcje, [1878], w: Pisma Stosława Łaguny, wyd. J. Bieliński, Warszawa 1915, s. 163; K. Maleczyński, Studya nad dyplomami i kancelaria Odonica i Laskonogiego 1202-1239, Lwów 1928, s. 161-162; J. Umiński, op. cit., s. 149-158. 
do Prus ${ }^{26}$, choć, niestety, nie wiemy nic bliższego o zadaniach, jakie powierzano im $\mathrm{w}$ czasie tych ekspedycji. Trudno też zgodzić się $\mathrm{z}$ opinią, że udział episkopatu w wiecu gąsawskim przemawia automatycznie za pokojowym charakterem tego zgromadzenia ${ }^{27}$. Niektóre źródła mówią bowiem wprost o przygotowaniach książąt polskich do wyprawy zbrojnej, inne zaś takiej możliwości nie przeczą. Stąd obecność sześciu biskupów w Gąsawie jesienią 1227 r. może być traktowana jako realizacja ciągle jeszcze aktualnego obowiązku, by na wezwanie książęce towarzyszyć monarsze i swoim diecezjanom na wojnie ${ }^{28}$. Z kolei jeśli chodzi o działających na pograniczu z krainami pogan biskupów płockich, to wydaje się, że dysponujemy wystarczającymi informacjami, by uznać, że gdy zachodziła taka potrzeba, osobiście bronili swej diecezji przeciwko pogańskim Prusom, tak jak to dowodnie miało miejsce już wcześniej w pierwszej połowie XII stulecia ${ }^{29}$. Obraz ten dopełnia zaangażowanie się wybitnych przedstawicieli Kościoła polskiego, przede wszystkim w osobach metropolity Henryka Kietlicza oraz kantora gnieźnieńskiego Pełki (późniejszego arcybiskupa), w głoszenie ideologii krucjatowej zarówno

26 Canonicorum Pragensium continuationes Cosmae, wyd. D.R. Köpke, Monumenta Germaniae Historica Scriptores, t. 9, Hannoverae 1851, s. 170; Preussisches Urkundenbuch, t. 1, cz. 1, wyd. R. Philippi, C.P. Wölky, Königsberg 1882, nr 41, 45-48; T. Jasiński, Stosunki śląsko-pruskie i ślasko-krzyżackie w pierwszej połowie XIII w., w: "Ars historica”. Prace z dziejów powszechnych i Polski, red. M. Biskup, H. Łowmiański, Poznań 1976, s. 393, 396-398; idem, Trzy nieznane oryginalne bulle Grzegorza IX dotyczace misji pruskiej z lat 1232-1234, "Zapiski Historyczne" 1988, 53, 3-4, s. 59-60; M. Gładysz, Zapomniani krzyżowcy. Polska wobec ruchu krucjatowego w XII-XIII wieku, Warszawa 2002, s. 182, 194-195.

27 B. Śliwiński, O charakterze zjazdu gąsawskiego i rzekomo majacej tam miejsce bitwie, „Studia z Dziejów Średniowiecza" 2015, 19, s. 196.

28 Chronica Polonorum, wyd. L. Ćwikliński, MPH, t. 3, Lwów 1878, s. 640 oraz 648; Chronica Poloniae Maioris, wyd. B. Kürbis, MPH, Nova series, t. 8, Warszawa 1970, s. 81-82; Annales, lib. 5-6, s. 247-250. Zob. ostatnio przegląd źródeł i opinii u J. Bieniaka, Polityczne okoliczności śmierci księcia Leszka Białego, w: Gąsawa w pamięci historycznej. W związu z 620. rocznica lokacji miasta, red. D. Karczewski, Inowrocław 2009, s. 35-60. Za wyprawę zbrojną uznał także ów zjazd N. Mika, Udział książąt ślaskich w wydarzeniach w Gasawie w 1227 roku, w: ibidem, s. 90-91.

29 Potwierdza to pamięć o związkach z wojną biskupów płockich, Gedki Sasinowica (1206-1223), który miał bronić swoją diecezję przed najazdami Prusów łzami i modlitwą i pobudzać miejscowe rycerstwo do obrony, oraz szczególnie pamięć o Gunterze (12281232), który miał mężnie powstrzymać atak Prusów, a zagarnięty przez nich gród zbrojnie odzyskać. Informacje te zawarte są w zachowanym do dziś, niestety tylko w przeróbce, katalogu biskupów płockich Jan Długosza. Obszerne uzasadnienie w J. Maciejewski, Memory. 
w odniesieniu do wypraw do Ziemi Świętej, jak również ekspedycji skierowanych przeciwko pogańskim Prusom ${ }^{30}$.

Paradoksalnie, pomimo dużego ilościowego wzrostu przekazów źródłowych odnoszących się do Polski, w kolejnych dziesięcioleciach znacznie trudniej śledzić związki episkopatu polskiego z wojną. Przede wszystkim w źródłach narracyjnych nie pojawiają się informacje o udziale biskupów polskich w książęcych wyprawach zbrojnych. Jedynym, dość specyficznym, wyjątkiem zdaje się być pamięć, zresztą wybiórcza, o wojennych dokonaniach biskupa krakowskiego Jana Muskaty. Co ciekawe, dziejopisarstwo polskie omawianego czasu nie stroni od przekazywania wiadomości o wojennym zaangażowaniu biskupów z krajów ościennych, zarówno jeśli chodzi o osobisty udział w wyprawach monarszych, pełnienie przez prałatów funkcji dowódczych, jak i samodzielne prowadzenie wojny ${ }^{31}$. Informacje te, choć niezbyt częste i lakoniczne, nie były dla przekazujących je autorów źródłem jakiejś konsternacji.

Zacznijmy zatem od weryfikacji narzucającej się po lekturze źródeł historiograficznych tezy, iż biskupi polscy od początku lat czterdziestych XIII w. przestali towarzyszyć monarchom w czasie wypraw zbrojnych ani też nie przyjmowali zadań militarnych od swoich książąt. Ciekawe w tym kontekście wydaje się porównanie z sytuacją na Węgrzech w czasie najazdu tatarskiego w roku 1241. Nie ma bowiem wątpliwości, że tamtejszy episkopat brał czynny udział w obronie kraju, wykonując różne nakazane przez króla zadania. Wśród nich przeważały zdecydowanie obowiązki związane bezpośrednio z wojna, na którą władca zwołał

30 M. Gładysz, op. cit., s. 149, 206-207; D. von Güttner Sporzyński, op. cit., s. 193-197, 214. Por. też W. Baran-Kozłowski, Arcybiskup gnieźnieński Henryk Kietlicz. Działalność kościelna i polityczna, Poznań 2005, s. 200-202. Brak już jednak potwierdzenia uczestnictwa biskupów w wyprawie opisanej przez Piotra Dusburga, a datowanej na rok 1234 lub 1235, Petri de Dusburg Chronicon terrae Prussiae, wyd. M. Töppen, Lipsiae 1861, s. 57-58; M. Gładysz, op. cit., s. 232-237; M. Dygo, Poczatki i budowa władztwa zakonu krzyżackiego (1226-1309), w: Państwo zakonu krzyżackiego w Prusach. Władza i społeczeństwo, red. M. Biskup, R. Czaja, Warszawa 2008, s. 65.

31 Rocznik kapituly gnieźnieńskiej, wyd. B. Kürbis, MPH, Nova series, t. 6, Warszawa 1962, s. 4; Rocznik kapituly poznańskiej, ibidem, s. 45; Chronica Poloniae Maioris, rozdz. 67 i 125; Rocznik małopolski, wyd. A. Bielowski, MPH, t. 3, s. 184; Rocznik Traski, wyd. A. Bielowski, MPH, t. 2, Lwów 1872, s. 852; Rocznik Sędziwoja, ibidem, s. 879. Być może należy też w tym duchu rozumieć zapiskę Rocznika górnośląskiego, wyd. A. Bielowski, MPH, t. 3, s. 715: „Bruno episcopus Olomutzensis Ratebor civitatem acquisivit". O tej ostatniej sprawie zob. A. Barciak, Biskup ołomuniecki Bruno z Schauenburga a Polska, „Śląski Kwartalnik Historyczny Sobótka” 1981, 36, 1, s. 73. W każdym razie tak to rozumiał Jan Długosz, Annales, lib. 7, s. 67. Dodać tu można jeszcze informacje Kroniki oliwskiej: Exordium ordinis cruciferorum seu Chronica de Prussia, wyd. W. Kętrzyński, MPH, t. 6, Kraków 1893, s. 290, 305, 307. 
także ordynariuszy z ich oddziałami. W trakcie przygotowań do odparcia inwazji biskupi należeli do grona doradców monarchy ${ }^{32}$. Choć później niektórzy z nich otrzymali inne polecenia, jak Stefan, biskup Vác, któremu Bela IV powierzył opiekę nad królową i zabiegi dyplomatyczne na dworze cesarskim ${ }^{33}$, to jednak wielu $\mathrm{z}$ nich wzięło udział $\mathrm{w}$ wojnie, na której dowodzili oddziałami, a także osobiście $\mathrm{z}$ mieczem $\mathrm{w}$ dłoni walczyli na polu bitwy, niekiedy wykazując duży zapał rycerski ${ }^{34}$. Zresztą pięciu biskupów węgierskich poległo, wraz z elitą tamtejszego rycerstwa i innymi duchownymi, $w$ największej bitwie stoczonej $w$ trakcie tych zmagań z Mongołami, 11 kwietnia 1241 r. nad rzeką Sajó ${ }^{35}$.

Tak dokładne informacje o sprawach węgierskich posiadamy jednak tylko dzięki szczęśliwemu zachowaniu dwóch wyjątkowych narracji, w tym jednej spisanej przez naocznego świadka wielu wojennych wydarzeń $^{36}$. A tymczasem te rycerskie, czy też szerzej ujmując wojenne, czyny węgierskich biskupów nie znalazły odzwierciedlenia w miejscowej historiografii. I na przykład w czternastowiecznej węgierskiej Kronice ilustrowanej brak jakiejkolwiek wzmianki o ordynariuszach walczących z Tatarami, co oczywiście mogło wynikać z bardzo różnych przyczyn ${ }^{37}$. Nie brak jednak innych źródeł, które potwierdzają osobiste zaangażowanie biskupów węgierskich, a przede wszystkim arcybiskupów Esztergom,

32 Magistri Rogeri Epistola in miserabile carmen super destructione regni Hungariae per Tartaros facta, tłum. i komentarz J.M. Bak, M. Rady, Central European Medieval Texts, 5, Budapest-New York 2010, s. 156; Thomae archidiaconi Spalatensis Historia Salonitanorum atque Spalatinorum pontificum, wyd. łac. O. Perić, tłum. i komentarz D. Karbić, M. Matijević Sokol, J.R. Sweeney, Central European Medieval Texts, 4, Budapest-New York 2006, s. 256.

33 Magistri Rogeri, s. 194.

34 Ibidem, s. 168-169, 178, 180; Thomae archidiaconi, s. 264; G. Barabás, Thirtheenth Century Hungarian Prelates at War, w: Between Sword and Prayer Warfare and Medieval Clergy in Cultural Perspective, red. R. Kotecki, J. Maciejewski, J.S. Ott, Leiden-Boston 2018, s. 43-47.

35 Magistri Rogeri, s. 182, 186, 188; Thomae archidiaconi, s. 268; M.C. Paul, Secular Power and the Archbishops of Novgorod Before the Muscovite Conquest, "Kritika: Explorations in Russian and Eurasian History" 2007, 8, 2, s. 240. J.Z. Pintér, Tatárok és magyarok (1241-1242), „Hadtörténelmi Közlemények” 2005, 118, 3, s. 672-683; G. Barabás, op. cit. s. 46.

36 Autor pierwszej relacji, magister Roger (zm. w 1266 r.), pochodził z Apulii i był kurialistą rzymskim, który kilka lat spędził na Węgrzech, gdzie otrzymał nawet archidiakonat w Oradei. W roku 1241 dostał się do niewoli tatarskiej, a po ucieczce z niej jego dalsza kariera była związana z Dalmacją, Magistri Rogeri, s. xliii-xliv. Z dalmatyńskiego punktu widzenia opisywał wspomnianą inwazję mongolską drugi z autorów, również dobrze wykształcony, archidiakon Splitu, Tomasz (zm. w 1268 r.), szerzej o jego życiu: Thomae archidiaconi, s. xxii-xxix.

37 Chronica de Gestis Hungarorum e Codice Picto Saec. XIV, wyd. i tłum. J.M. Bak, L. Veszprémy, Budapest-New York 2018, s. 324, 326. 
w wojny prowadzone przez Arpadów przez cały wiek XIII ${ }^{38}$. Prałatów węgierskich widzimy także później w kampanii antytureckiej $\mathrm{w}$ roku 1444, a niektórzy z nich ponieśli śmierć w bitwie pod Warną ${ }^{39}$. Można zatem sądzić, że związki węgierskiego episkopatu z wojną były bardzo bliskie $\mathrm{w}$ całym interesującym nas okresie.

Biorąc to wszystko pod uwagę, z dużą nieufnością można by traktować obserwację, iż znane nam źródła nie przekazały żadnej informacji o udziale biskupów polskich w odparciu najazdu tatarskiego w roku 1241. Tym bardziej że wiemy o nim w ogóle znacznie mniej niż o wypadkach, które rozegrały się na Węgrzech. Trudno jednak nie docenić faktu, że z pewnością żaden ze zwierzchników polskiej diecezji nie zginął w czasie owego najazdu ${ }^{40}$. Nie zachowała się także pamięć o jakimkolwiek, choćby modlitewnym, zaangażowaniu się biskupa polskiego w obronę kraju czy konkretnej miejscowości, zaś oblężony przez Tatarów zamek wrocławski, według zapisanej przez Długosza tradycji, zapewne dominikańskiej, miał zostać uratowany nie przez modlitwy swojego ordynariusza, ale dzięki oratione cum lachrimis dominikanina Czesława Odrowąża ${ }^{41}$. Można by zatem sądzić, iż właśnie zamęt spowodowany najazdem tatarskim wsparł mocno procesy emancypacyjne Kościoła polskiego i pomógł wyzwolić mu się spod dominacji władzy świeckiej, także w sferze obowiązków wojskowych. Nie ma bowiem żadnych wątpliwości, że rywalizujący ze sobą o ziemie i władzę książęta piastowscy trzymali znacznie słabiej ster rządów niż na przykład współcześni im królowie węgierscy. A konflikty w łonie polskiej dynastii mogły rodzić wątpliwości, czy duchowny powinien uczestniczyć w wojnie przeciwko chrześcijanom.

Ciekawe, że dokumenty immunitetowe, które biskupi polscy otrzymywali od miejscowych książąt, nie mają w interesującej nas tu kwestii, poza jednym przypadkiem, nic do powiedzenia. Pokazują one oczywiście, że od początku XIII w. zintensyfikowany został proces uzyskiwania

\footnotetext{
38 G. Barabas, op. cit., s. 48-55.

39 Codex epistolaris saeculi decimi quinti, t. 2, wyd. A. Lewicki, Kraków 1891, nr 308; Annales, lib. 12, s. 319-320; 328-329. J. Ptak, Duszpasterstwo, s. 104, sformułował nawet tezę o wyjątkowości Węgier, jeśli chodzi o zaangażowanie zbrojne episkopatu, która choć nie wydaje się słuszna, to sygnalizuje dobrze różnice, jakie można dostrzec między sytuacją w Polsce i na Węgrzech.

40 J. Maciejewski, Episkopat polski doby dzielnicowej 1180-1320, Kraków-Bydgoszcz 2003, s. 226, 233, 239, 247, 255, 263, 268.

41 Annales, lib. 7, s. 18. Szerzej o kulcie bł. Czesława: J.A. Spież, Średniowieczne świadectwa życia i kultu błogosławionego Czesława, w: Dominikanie w środkowej Europie w XIII-XV wieku. Aktywność duszpasterska i kultura intelektualna, red. J. Kłoczowski, J.A. Spież, Poznań 2002, s. 87-108; W. Kucharski, „Beatus Ceslaus natione Polonus”. Dzieje kultu błogosławionego Czestawa, Kraków 2012.
} 
przez instytucje kościelne zwolnień od wszelkich ciężarów wojskowych. W wyniku tego ludność zamieszkująca dobra biskupie została uwolniona także od udziału w ekspedycjach zbrojnych, $\mathrm{z}$ reguły jednak z zastrzeżeniem uczestnictwa $\mathrm{w}$ wojnie obronnej, a na Mazowszu także $\mathrm{w}$ wyprawie generalnej przeciwko Prusom ${ }^{42}$. Odnośne dokumenty nie zajmują się kwestią udziału w wojnie duchowieństwa, w tym biskupów. Wyjątkiem jest przywilej Bolesława Wstydliwego z 13 czerwca 1258 r., w którym wyraźnie zaznaczono, że biskup został zwolniony wraz ze swoją kapitułą i z całym duchowieństwem od uczestniczenia w wyprawie zarówno w obrębie granic księstwa, jak i zagranicznej. Nawet w przypadku najazdu Litwinów na wojnę mieli się stawić tylko ludzie z dwóch kasztelanii majątkowych Kościoła krakowskiego ${ }^{43}$. Nie wiemy, czy było to powtórzenie jakiegoś wcześniejszego, dziś nieznanego zwolnienia. Jednak brak podobnych klauzul w dokumentach innych książąt piastowskich wskazuje raczej na to, że mamy do czynienia z zapisem unikalnym, wychodzącym poza zwykły formularz zwolnień. Dyplom ten w każdym razie zdaje się potwierdzać, że od biskupów krakowskich wcześniej można było wymagać, by wyprawiali się osobiście wraz ze swoim otoczeniem razem $\mathrm{z}$ władcą na wojnę.

Trudno jednoznacznie odpowiedzieć na pytanie, dlaczego powyższe zwolnienie uzyskało wyłącznie biskupstwo krakowskie i czemu ono służyło, skoro wszystko wskazuje na to, że pozostali ordynariusze polscy także nie uczestniczyli w wyprawach zbrojnych książąt. Spróbujmy spojrzeć na ten problem z szerszej perspektywy, biorąc pod uwagę kraje, gdzie rywalizacja o tron monarszy łączyła się ze wzrostem wpływów papieskich i gotowością miejscowych Kościołów do realizacji ideałów reformistycznych, również w odniesieniu do uczestnictwa duchowieństwa w wojnie.

Całkiem nieźle źródła oświetlają sytuację w Norwegii, gdzie w drugiej połowie XII w. władca zagwarantował biskupom i duchowieństwu zwolnienie od obowiązku chwytania za broń oraz uczestnictwa w ekspedycjach zbrojnych. Zrobiono wszakże wyjątek dla zgromadzenia zwanego stepnoleidinge, a także najazdu pogan. Dość szybko tamtejszy Kościół

42 Codex diplomaticus et commemorationum Masoviae generalis, wyd. J.K. Kochanowski, Warszawa 1919, nr 396 (dokument księcia Konrada i jego syna Bolesława dla biskupstwa płockiego).

43 Kodeks dyplomatyczny katedry krakowskiej św. Wactawa [dalej: KKK], t. 1-2, wyd. F. Piekosiński, Kraków 1874-1883, 1, nr 59. Było to jeszcze aktualne za czasów Kazimierza Wielkiego, który domagał się od biskupa krakowskiego przysłania z kasztelanii kościelnych doświadczonych wojaków (homines suos bellicuosos) dla odparcia najazdu Litwinów, Tatarów czy Rusinów, J. Dąbrowski, Obowiązek obrony kraju w XI-XIII wieku, „Sprawozdania z Czynności i Posiedzeń Polskiej Akademii Umiejętności" 1951, 52, 10, s. 887. 
postarał się też o papieską wykładnię obowiązującego w tym zakresie prawa, która sprowadzała się do całkowitej prohibicji wojskowej dla biskupów, opatów i innych duchownych, „cum ipsi regalia non habeant”44. Jednak i w tym przypadku przewidywano możliwość chwycenia za broń i pójścia kleru na wojnę w sytuacji szczególnej konieczności. A skoro biskup miał zezwalać na to swoim podwładnym, to należy przyjąć, że sam także mógł podjąć decyzję o swoim udziale w wojnie. Istotnym aspektem tej sprawy jest to, że statuty synodu norweskiego zapewne z 1164 r. (Canones Nidrosiensis) oparte są w znacznym stopniu na Dekrecie Gracjana, który był z pewnością świetnie znany w Polsce i zapewne także tutaj wywierał wpływ na kształtowanie się stosunków Kościoła z dworami książęcymi ${ }^{45}$.

Ale właśnie przykład norweski pozwala spojrzeć na omawianą kwestię również z nieco innej perspektywy, nie tylko obowiązujących duchownych nakazów czy zwolnień, ale także aktualnych relacji między dworem monarszym a władzą duchowną, pozycji politycznej prałatów czy też aktualnego stanu poglądów na militarne zaangażowanie kleru w sprawy militarne wśród elity duchownej i świeckiej kraju. Pomimo bowiem uzyskania przez duchowieństwo norweskie wspomnianych zwolnień oraz otrzymania od papiestwa jasnych interpretacji potępiających angażowanie się duchowieństwa w kwestie militarne, niektórzy tamtejsi biskupi nadal aktywnie uczestniczyli w wojennych przedsięwzięciach świeckich panów, w tym także w rywalizacji o tron królewski, a miejscowi komentatorzy tych działań oceniali je przede wszystkim z punktu widzenia lojalności czy nielojalności względem tego czy innego kandydata do tronu, a nie wypełniania nakazów prawa kościelnego. Podkreślić zaś trzeba, że udział biskupów nie ograniczał się tylko do używania całego arsenału środków religijnych czy dyplomatycznych, lecz obejmował także osobiste uczestnictwo w kampaniach zbrojnych, choć raczej z zachowaniem wstrzemięźliwości, jeśli chodzi o noszenie broni czy przelewanie krwi ${ }^{46}$.

44 W. Holtzmann, Krone und Kirche in Norwegen im 12. Jahrhundert (Englische Analekten III), „Deutsches Archiv für Geschichte des Mittelalters” 1938, 2, s. 368, 378. Duchowieństwo, według króla Magnusa, miało także różnymi sposobami duszpasterskimi działać na rzecz pomyślnego zakończenia walk.

45 A. Winroth, "Decretum Gratiani" and Eystein's "Canones Nidrosienses", w: Archbishop Eystein as Legislator: The European Connection, red. T. Iversen, Trondheim 2011, s. 73-86. W sprawie recepcji Gracjana w Polsce zob. A. Vetulani, Przenikanie zasad powszechnego prawa kanonicznego i prawa rzymskiego do piastowskiej Polski, w: idem, Z badań nad kultura prawnicza w Polsce piastowskiej, Wrocław 1976, s. 95-114.

46 L. Taylor, Bishops, War and Canon Law. The military activities of Prelates in High Medieval Norway, „Scandinavian Journal of History” 2019, s. 1-23, https://doi.org/10.1080/03468755.2 019.1684356 . 
Dążenie do zniesienia obowiązku pociągania duchownych na wyprawy zbrojne zaobserwować można także w XII w. na Półwyspie Pirenejskim. W Kastylii już w roku 1129 synod w Palencii, któremu przewodniczył król Alfons I oraz arcybiskup Toledo, Rajmund, zabronił żądać od kleru, by szedł na wojnę, nosił broń i robił cokolwiek wbrew prawu kanonicznemu ${ }^{47}$. Ale tym koncesjom brak było znamion trwałości, gdyż w okresie późniejszym uczestnictwo biskupów w wyprawach zbrojnych tamtejszych władców było norma, a czynny udział episkopatu w wojnach był akceptowany przez normy społeczne ${ }^{48}$. Wątpliwości budził jedynie udział duchownych w wojnie z chrześcijanami. Stąd na przykład król Alfons X Mądry (1221-1284) zwalniał kler w takim przypadku z obowiązku towarzyszenia armii ${ }^{49}$.

Mimo napięć, które można obserwować w kolejnych stuleciach w stosunkach między władzą świecką a duchowną, zobowiązania militarne biskupów, w tym także powoływanie ich osobiście na wyprawę zbrojna, były nadal aktualne wszędzie tam, gdzie władza monarsza była silna, a miejscowe elity akceptowały tego typu służbę duchownych. Należy wszakże pamiętać, że wojowniczy, osobiście biorący udział w walce biskupi stanowili zdecydowaną mniejszość, a także i o tym, że nawet na terenie cesarstwa nie wszyscy ordynariusze na wojnę chodzili, lecz tylko ci, którzy szczególnie dbali o swoje interesy i bliskie związki z dworem ${ }^{50}$. Zresztą na terenie Rzeszy w XIII stuleciu, w związku ze znacznym osłabieniem, a przejściowo nawet zanikiem, władzy cesarskiej także możemy obserwować rozluźnienie więzów między episkopatem a władzą centralną. Tamtejsi biskupi używali jednak niebagatelnych zasobów materialnych, by wzmacniać swoją siłę wojskową i dzięki niej budować lub poszerzać swe władztwa terytorialne. Przez to ich aktywność wojskowa wcale nie malała, gdyż stawali się niejednokrotnie aktywną stroną w lokalnych

47 Historia compostelana, tłum. E. Falque, Madrid 1994, s. 504; F. Reilly, The Kingdom of León-Castilla Under King Alfonso VII, 1126-1157, Philadelphia 1998, s. 28; L.G. Duggan, op. cit., s. 160.

48 C. de Ayala Martínez, The Episcopate and Reconquest in the Times of Alfonso VII of Castile and León, w: Between, s. 207-232; P. Dorronzoro Ramírez, The Aragonese Episcopate and the Military Campaigns of Alfonso I the Battler against Iberian Muslim, w: ibidem, s. 233-273; K.C. Lincoln, op. cit., s. 6-17.

49 A. Arranz Guzmán, op. cit., s. 277-278.

50 N. Lund, op. cit., s. 307; S. Schild, op. cit., s. 140-141; J. Baldwin, The Government of Philip Augustus. Foundations of French Royal Power in the Middle Ages, Berkeley-Los Angeles-Oxford 1986, s. 281-286; J.-P. Stöckel, op. cit., s. 63-79; T. Reuter, „Episcopi cum militia sua”. The Prelate as Warrior in the Early Staufer Era, w: Warriors and Churchmen in the High Middle Ages. Essays presented to Karl Leyser, red. idem, London-Rio Grande 1992, s. 83-88; H. Hoffmann, op. cit., s. 109-124. 
konfliktach zbrojnych ${ }^{51}$. Podobnie na Pomorzu Zachodnim, gdzie od połowy XIII stulecia kolejni biskupi kamieńscy budowali swoje władztwo terytorialne, własne siły zbrojne stały się dla tego biskupstwa podstawą prowadzenia aktywnej, a nawet ekspansywnej polityki zagranicznej ${ }^{52}$.

Na terenie domeny piastowskiej już w początkach XIII stulecia część książąt wyraziła generalną aprobatę dla obowiązywania $\mathrm{w}$ kraju prawa kanonicznego i podstawowych wolności kościelnych. Wprowadzany w Polsce intensywnie od czasów bliskiej współpracy arcybiskupa gnieźnieńskiego Henryka Kietlicza z papieżem Innocentym III program libertas ecclesiae miał szeroki zakres znaczeniowy i był skupiony na uwolnieniu Kościoła lokalnego od wpływów świeckich ${ }^{53}$. Służyła temu wolna elekcja kanoniczna biskupów, której konsekwencją było powierzanie urzędu osobom dobrze zintegrowanym z miejscowym Kościołem i zobowiązanych do dbania przede wszystkim o jego interesy. Przemianie tej towarzyszyła dezaktualizacja wzoru biskupa służącego panującemu i odejście episkopatu od służby dworskiej, gdyż w całym interesującym nas okresie żaden $\mathrm{z}$ biskupów nie piastował już, jak to bywało w czasach wcześniejszych, a także później w dobie Jagiellonów, urzędu kanclerskiego, nawet wówczas, gdy przed wstąpieniem na katedrę był związany z kancelarią monarszą4.

Rozluźnienie formalnych związków biskupów z dworem panującego mogło mieć także naturalne konsekwencje w odniesieniu do obowiązku osobistego udziału w wyprawie zbrojnej. W programie arcybiskupa Henryka Kietlicza ten ostatni element samodzielnie nie występuje, ale wpisywałby się dobrze w starania duchowieństwa, które widoczne są w innych krajach. W Polsce faktyczna realizacja tego postulatu przypadła na epokę dzielnicową po najeździe mongolskim, lecz nie stała się, być

51 B. Arnold, Medieval German Bishops and their Military Retinues in the Medieval Empire, „German History" 1989, 7, 2, s. 166.

52 B. Śliwiński, Pomorze Wschodnie w okresie rządów księcia polskiego Władysława Łokietka w latach 1306-1309, Gdańsk 2003, s. 67-70, 229-234; D. Wybranowski, Przydatność źródet zachodniopomorskich z XII-XIII wieku w badaniach nad dziejami wojen i wojskowościa średniowiecza, w: Formuła - Archetyp - Konwencja w źródle historycznym, red. A. Górak, K. Skupieński, Lublin 2006, s. 322-323, 329.

53 J. Wyrozumski, Kościót i społeczeństwo polskie w świetle bulli papieża Innocentego III, w: Człowiek w społeczeństwie średniowiecznym, red. R. Michałowski et al., Warszawa 1997, s. $110,113-115$.

54 C. Deptuła, Biskup i władca. Z problematyki ideologii państwowej i świadomości narodowej polskiego średniowiecza, „Więź" 1968, 11, 9, s. 52; S. Kwiatkowski, Powstanie i kształtowanie się chrześcijańskiej mentalności religijnej w Polsce do końca XIII w., Warszawa 1980, s. 169-171, 179; J. Maciejewski, Episkopat, s. 82-84, 214-215 T. Graff, Episkopat monarchii jagiellońskiej w dobie soborów powszechnych XV wieku, Kraków 2008, s. 74-75. 
może $\mathrm{z}$ braku potrzeby, ani częścią ustawodawstwa kościelnego, ani nie weszła do kanonu zwolnień immunitetowych udzielanych przez książąt piastowskich.

Jeśli chodzi o przywilej krakowski z roku 1258, to Józef Matuszewski sądził, że dokument wydano, by rozszerzyć wcześniejsze zwolnienia militarne nadane biskupstwu krakowskiemu o wojnę obronną ${ }^{55}$. Jeśli nawet tak było, to świątobliwy biskup Prędota wykorzystał okazję, by uzyskać dodatkowe zwolnienie dla siebie i podległego mu kleru. Mogło tu chodzić z jednej strony o przekonanie, że zasiadający na tronie krakowskim Bolesław, potomek ogólnopolskich władców, jako jedyny ma uprawnienia do powoływania duchownych pod broń. Z drugiej strony, i to wydaje się być ważniejsze, o zwycięstwo w otoczeniu tego zasłużonego dla obrony interesów Kościoła biskupa poglądów o odseparowaniu duchowieństwa od spraw militarnych, pozostawiając mu jedynie możliwość udzielania religijnego wsparcia władcy i jego armii. Tak też kwestie te traktuje omawiany dyplom, gdzie czytamy, że biskup i jego duchowni nie mają chodzić na wojnę, aby mogli skupić się na służbie Bożej i modlitwie ${ }^{56}$. W tę narrację dokumentu książęcego dobrze wpisują się doniesienia annalistów krakowskich o bitwie pod Wrotami w czerwcu 1266 r., gdzie książę Bolesław Wstydliwy miał zwyciężyć Szwarna, syna Daniela Halickiego, nie ze względu na swoje męstwo, lecz dzięki modlitwie Kościoła i Bożej pomocy ${ }^{57}$. W przekazach tych odnajdujemy dość powszechne w średniowieczu przekonanie, że modlitwa może być skuteczna także gdy jest zanoszona $\mathrm{w}$ miejscu oddalonym od działań zbrojnych, a zwycięstwo nie zależy od wielkości armii, lecz od pomocy płynącej z niebios ${ }^{58}$. Tego typu publiczne modły były od czasów karolińskich odprawiane na

55 J. Matuszewski, Immunitet ekonomiczny w dobrach kościoła w Polsce do 1381 roku, Poznań 1936, s. 190.

56 KKK, t. 1, nr 59: „Insuper ut Episcopus cum clero suo possit diuinis laudibus liberius insistere et inuigilare presertim hostilitatis tempore oracionibus...".

57 Rocznik kapituty krakowskiej, wyd. Z. Kozłowska-Budkowa, MPH, Nova series, t. 5, Warszawa 1978, s. 92: „....non tantum propria virtute, sed oracionibus ecclesie et superno auxilio adiuvante. Nec hec victoria est humanis viribus sed pocius divine potentie asscribenda". Tak samo: Rocznik kujawski, wyd. A. Bielowski, MPH, t. 3, s. 206; Katalogi biskupów krakowskich, wyd. J. Szymański, MPH, Nova series, t. 10, cz. 2, Warszawa 1974, s. 99 (redakcja dominikańska). W pierwszym z cytowanych tu roczników, w redakcji z roku 1266, (s. 69-70) znajduje się także zapiska o zwycięstwie wojsk Leszka i Konrada pod Zawichostem w 1205 r., gdzie Kazimierzowice mieli odnieść zwycięstwo „cooperante Omnipotentis auxilio", choć siły ich były niewielkie. W tym samym duchu sformułował generalny wniosek dotyczący czynnika decydującego o zwycięstwie w wojnie autor Thomae archidiaconi, s. 335 .

58 D.S. Bachrach, op. cit., s. 155; J. Maciejewski, Biskup, s. 422. 
życzenie władcy przez duchowieństwo diecezjalne pod przewodnictwem miejscowego biskupa ${ }^{59}$. Dokładniejsze dane o podobnych oracjach zanoszonych przez kler polski z inspiracji i nakazu biskupów w czasie wojennej wyprawy królewskiej posiadamy jednak dopiero z czasów ekspedycji antytureckiej Władysława Warneńczyka w roku $1443^{60}$.

Cytowany powyżej dyplom księcia Bolesława z roku 1258 stanowi jedyne potwierdzenie, że za brakiem informacji w źródłach historiograficznych o wojennych wyprawach biskupów wraz z armią monarszą kryje się przekonanie polskich elit kościelnych, że duchowni, w tym biskupi, nie powinni brać udziału w wyprawach zbrojnych. Trzymaniu się przez episkopat z dala od ekspedycji zbrojnych książąt sprzyjał zapewne fakt, że choć stolica biskupia w ówczesnej Polsce była najczęściej jednocześnie rezydencją jakiegoś księcia, to granice diecezji zupełnie nie pokrywały się z granicami księstw piastowskich, co nie sprzyjało utrzymywaniu się zależności konkretnego biskupa tylko od jednego księcia.

Wkrótce jednak sytuacja zaczęła się zmieniać, gdyż na przełomie XIII i XIV w. pojawiła się ponownie znacznie silniejsza władza monarsza na ziemiach polskich, a współpraca niektórych prałatów z dworem królewskim owocowała nie tylko politycznym wsparciem udzielanym władcy przez biskupa, ale nawet wypełnianiem przez ordynariusza obowiązków urzędnika monarszego. Za klasyczny przykład może tu służyć działalność biskupa krakowskiego Jana Muskaty, który blisko współpracował z dworem praskim, starał się o urząd wicekanclerza na Węgrzech, a później został starostą króla czeskiego w Krakowie ${ }^{61}$. Brak co prawda bezpośrednich dowodów na to, że hierarcha ten uczestniczył w monarszych ekspedycjach zbrojnych, ale z drugiej strony wiadomo, że z pewnością prowadził on działania zbrojne $\mathrm{w}$ imieniu Wacława II, a później jego następcy, broniąc czeskiego panowania w Małopolsce ${ }^{62}$. Jeśli zaś chodzi o wspomniane wyprawy królewskie, to pamiętać należy, że biskup Jan wziął udział w ekspedycji obu Przemyślidów na Węgry w 1301 r., gdzie był w pierwszym okresie pobytu tamże jednym z ważniejszych doradców

\footnotetext{
59 D.S. Bachrach, op. cit., s. 107, 122-123, 138.

60 K. Spurgjasz, Modlitwy o zwycięstwo w kościołach polskich w 1443 roku, w: Wojna a religia w średniowieczu, red. M. Zapiór, Kraków 2009, s. 105-111. Zwyczaj ten korespondował ściśle z modłami zanoszonymi przez kler towarzyszący armii w trakcie bitwy, na co w odniesieniu do ziem polskich dowodów nie brakuje.

61 S. Sroka, Z dziejów stosunków polsko-węgierskich w późnym średniowieczu: szkice, Kraków 1995, s. 22-28; T. Pietras, "Krwawy wilk z pastoratem”. Biskup krakowski Jan zwany Muskata, Warszawa 2001, s. 56.

62 T. Pietras, op. cit., s. 66-73.
} 
młodego Władysława V (syna Wacława II czeskiego) ${ }^{63}$. A przecież młody Przemyślida udał się na Węgry z wielkim wojskiem, gdyż Czesi musieli liczyć się w targanym wojną domową kraju z możliwością oporu koronowanego już wcześniej na tamtejszego króla Karola Roberta ${ }^{64}$. Ostatecznie nie doszło wówczas do żadnych poważniejszych walk, ale w czasie pobytu nad Dunajem Muskata był przez papieża Bonifacego VIII niedwuznacznie oskarżany o sianie niezgody, wzniecanie wojen i inną działalność niegodną biskupa ${ }^{65}$. Trudno orzec, czy to właśnie do tego okresu odnosi się stawiany Janowi już w trakcie pierwszego procesu zarzut mężobójstwa, bowiem nie został on wówczas sprecyzowany ${ }^{66}$.

Nieprzychylność papieża wobec Przemyślidów i ich zwolenników wykorzystali przeciwnicy polityczni biskupa Muskaty w Polsce, z arcybiskupem Jakubem Świnką na czele. Ten ostatni, będąc zwolennikiem księcia Władysława Łokietka, próbował zmusić biskupa krakowskiego do rezygnacji z realizacji jego własnych celów politycznych, nawet jeśli były one korzystne dla biskupstwa krakowskiego, gdyż zakładały budowę biskupiego władztwa terytorialnego ${ }^{67}$. Treść zeznań świadków przesłuchiwanych podczas drugiego z tych procesów kanonicznych (1306-1308) mocno wiązała się z krytyką jego działalności świeckiej, w tym również związków tego hierarchy ze sferą militarna gdyż z dużą determinacją bronił on zbrojnie panowania Wacławów. Wspomniani świadkowie twierdzili, że biskup prowadził wojnę i uważali, że w związku z tym jest odpowiedzialny za stosowanie przemocy, a także zadawanie ran i śmierci przez wysyłanych przez niego do boju żołnierzy. Miał też Muskata nie tylko wydawać rozkazy swoim oddziałom, ale także błogosławić ich broń oraz utrzymywać bliskie kontakty z wojownikami. Z zeznań tych wynika

63 KKK, t. 1, nr 105; T. Pietras, op. cit., s. 56; J. Libor, Václav II. Král na strúbrném trưnu 1283-1305, Praha 2015, s. 313.

64 Chronicon Aulae Regiae, wyd. J. Emler, Fontes Rerum Bohemicarum, t. 4, Praga 1884, s. 84: „cum innumera multitudine”; Chronica de Gestis Hungarorum, s. 346: „cum multitudine exercitus pannoniam est ingressus"; S. Sroka, op. cit., s. 20-22; T. Pietras, op. cit., s. 55-56; J. Libor, op. cit., s. 311-312.

65 Vetera Monumenta Historica Hungariam Sacram Illustrantia, t. 1, wyd. A. Theiner, Romae 1859, nr 624; Vetera Monumenta Poloniae et Lithuaniae, t. 1, wyd. A. Theiner, Romae 1860, nr 199; W. Abraham, op. cit., Kraków 1893, s. 13.

66 MPV, t. 3, nr 111; J. Maciejewski, Making War and Enormities: Violence within the Church in Diocese of Cracow at the Beginning of 14th Century, w: Ecclesia et Violentia: Violence against the Church and Violence within the Church in the Middle Ages, red. R. Kotecki, J. Maciejewski, Newcastle upon Tyne 2014, s. 144.

67 S. Gawlas, Człowiek uwikłany w wielkie procesy - przykład Muskaty, w: Człowiek, s. 393-400. 
wreszcie, że Jan Muskata brał bez wątpienia osobiście udział w niektórych operacjach zbrojnych ${ }^{68}$.

Co ciekawe, te wielorakie związki biskupa krakowskiego Jana Muskaty ze sferą militarną są słabo widoczne w historiografii średniowiecznej, szczególnie jeśli poszukujemy bliższych szczegółów jego działalności. Tylko pochodzący z początków XIV w. rocznik franciszkański wspomina o prowadzeniu wojny przez biskupa Muskatę ${ }^{69}$, a informację tę powtórzyły później niektóre redakcje katalogów biskupów krakowskich, zaś jedna z nich wykreowała tę postać na antywzorzec biskupa oraz człowieka niezwykle niebezpiecznego ${ }^{70}$. To jednak znamienne, że właśnie Rocznik małopolski, źródło genetycznie związane z modelowaniem nowego ujęcia dziejów polskich po okresie rozbicia dzielnicowego, wskazało na aktywność wojenną ordynariusza występującego przeciwko piastowskiemu monarsze. Podobnie ma się rzecz z tzw. dominikańskim katalogiem biskupów krakowskich, który w świetle nowszych badań wiąże się z kręgiem kapituły krakowskiej, gdyż wykorzystywał źródła przechowywane na Wawelu ${ }^{71}$. Natomiast Jan Długosz, w końcu kanonik katedry krakowskiej, nie miał prawie nic do powiedzenia o tym biskupie, jakby jego wojownicza działalność nie była mu znana ${ }^{72}$. Można odnieść wrażenie, że pamięć o czynach Muskaty w XV-wiecznym krakowskim środowisku kapitulnym była bardzo słaba, a być może poddana celowym zabiegom damnatio memoriae.

\footnotetext{
68 MPV, t. 3, nr 121; J. Maciejewski, Making, s. 164.
}

69 Rocznik małopolski, s. 188: „Item Johannes episcopus capitur a duce propter gwerras quas faciebat". W sprawie datacji i proweniencji tego źródła zob. W. Drelicharz, Annalistyka małopolska XIII-XV wieku. Kierunki rozwoju roczników kompilowanych, Kraków 2003, s. 374-468, szczeg. 453; J. Banaszkiewicz, Rocznik tzw. małopolski (minorycki) z poczatku XIV wieku - próba dookreślenia zabytku, w: Przeszłość w kulturze średniowiecznej Polski, t. 1, red. idem, A. Dąbrówka, P. Węcowski, Warszawa 2018, s. 353-354, 364-365.

70 Katalogi biskupów, s. 65 (redakcja IV świętokrzyska), „Hic captus fuit a duce Vladislao Loktek propter gwerras, quas faciebat"; niemal identycznie s. 102 (redakcja V dominikańska), s. 114 (redakcja lubelska); S. Gawlas, Człowiek, s. 393.

71 G. Labuda, O katalogach biskupów krakowskich przed Długoszem, „Studia Źródłoznawcze" 1983, 27, s. 83-96; W. Drelicharz, op. cit., s. 148-149; M. Zdanek, op. cit., s. 259-260.

72 Annales, lib. 8, s. 287, lib. 9, s. 109; Katalogi biskupów, s. 183-186, gdzie jedynie na podstawie dokumentu Łokietka z 2 IX 1306 r. (KKK, 1, nr 114) informacja o uwięzieniu biskupa przez pewnych rycerzy z powodu jego wrogiego stosunku do księcia Władysława. Niektórzy badacze domyślają się, że pewne występki Muskaty przypisano w tradycji krakowskiej biskupowi Pawłowi z Przemykowa, co też potem przejął Długosz. Zob.: A. Rybarski, Udział Toporczyków w uwięzieniu biskupa krakowskiego, „Kwartalnik Historyczny” 1912, 26, s. 1; W. Karasiewicz, Pawet z Przemankowa biskup krakowski 1266-1292, „Nasza Przeszłość” 1956, 9, s. 234-240; J. Gawron, Czarna legenda biskupa krakowskiego Pawła z Przemankowa, „Annales Universitatis Mariae Curie-Skłodowska. Sectio F, Historia” 2016, 71, s. 56-57. 
Warto wspomnieć, że bliskie związki biskupa krakowskiego z dworem królewskim były naturalne w monarchii ostatnich Przemyślidów, podobnie jak i powierzanie zadań wojennych hierarchom kościelnym. Wystarczy przypomnieć, że w roku 1291 wojsko czeskie, które obsadziło Kraków, zostało przyprowadzone przez biskupa bamberskiego Alberta von Solmsa ${ }^{73}$. Ciekawe, że autor Kroniki Zbrasławskiej uznał to za rzecz w Czechach tak naturalna, że pomyłkowo dowództwo to przypisał biskupowi praskiemu Tobiaszowi ${ }^{74}$. Natomiast współczesny Muskacie inny sufragan gnieźnieński, Henryk z Wierzbnej, był także przez krótki czas starostą królewskim we Wrocławiu, lecz o jego działalności na tym urzędzie właściwie nic nie wiadomo ${ }^{75}$.

Podobne tendencje spotykamy w Polsce na początku rządów królewskich Władysława Łokietka, gdyż we wczesnych latach dwudziestych XIV stulecia arcybiskup gnieźnieński Janisław, jeden z najbliższych współpracowników króla, pełnił urząd starosty brzeskiego na Kujawach, a kaliskiego w Wielkopolsce ${ }^{76}$. Nic nie wiemy, by ta działalność arcybiskupa spotkała się z jakąś niechęcią czy krytyką77. Coś jednak mogło być na rzeczy, skoro sam Janisław, zeznając w 1339 r. na procesie przeciwko Krzyżakom, stwierdził, że był starostą Łokietka „cum esset in minoribu$\mathrm{s}^{\prime \prime 78}$, co niezależnie od tłumaczenia wygląda na próbę ukrycia faktu, że urząd starosty sprawował, będąc metropolitą gnieźnieńskim ${ }^{79}$. Z drugiej

73 Rocznik Traski, s. 852; Rocznik Sędziwoja, s. 879; B. Nowacki, Czeskie roszczenia do korony w Polsce w latach 1290-1335, Poznań 1987, s. 44; J. Libor, op. cit., s. 136.

74 Chronicon Aulae, s. 45; B. Nowacki, Przemyst II. Odnowiciel Korony Polskiej (1257-1296), Kraków 2017, s. 171.

75 Codex diplomaticus Silesiae, t. 16, wyd. C. Grünhagen, K. Wuttke, Breslau 1892, nr 2844; P. Hoffmann, Heinrich von Würben, Bischof von Breslau, Breslau 1904, s. 18.

76 M. Komaniecka, Działalność polityczna arcybiskupa Janisława, „Nasza Przeszłość” 2005, 103, s. 100-103.

77 J. Maciejewski, Episkopat, s. 147.

78 Lites (1339), s. 369.

79 Możliwe są tutaj dwa tłumaczenia: 1) za młodu; 2) mając święcenia niższe. W przypadku tego drugiego wariantu mielibyśmy do czynienia z oczywistym kłamstwem, ale także określenie „za młodu” w odniesieniu do lat dwudziestych XIV w. jest w przypadku Janisława nadużyciem. W roku 1304 był on bowiem kanonikiem gnieźnieńskim i rektorem tamtejszej szkoły katedralnej, zaś trzy lata później potwierdzony jest jego uniwersytecki tytuł magistra, gdy sprawuje już urząd oficjała biskupiego w Gnieźnie (MPV, t. 3, nr 114). Wynika z tego, głównie ze względu na czas potrzebny do ukończenia studiów zagranicznych, że musiał urodzić się co najmniej kilka lat przed rokiem 1290, trudno by więc było go nazwać w roku 1321 młodzieńcem, Kodeks dyplomatyczny Wielkopolski, t. 6, wyd. A. Gąsiorowski, H. Kowalewicz, Poznań 1982, nr 74; MPV, t. 3, nr 114; K. Ożóg, Intelektualiści w stużbie Królestwa Polskiego w latach 1306-1382, Kraków 1995, s. 129; J. Maciejewski, Episkopat, s. 229-230; M. Komaniecka, op. cit., s. 94-95. 
strony, jak pokazał ostatnio Craig Nakashian na przykładzie biskupów angielskich, zaś Louisa Taylor badając podobne kwestie w odniesieniu do hierarchów norweskich, ich działalność świecka, w tym angażowanie się w konflikty militarne, była przez współczesnych oceniana przede wszystkim ze względu na powody, dla których podejmowali się tych działann ${ }^{80}$. Wiele wskazuje na to, że również w Polsce takie podejście elit duchownych i świeckich do militarnej służby biskupów było aktualne.

Pewne analogie do udziału Muskaty w węgierskiej wyprawie Przemyślidów możemy zresztą dostrzec w jesienno-zimowej ekspedycji Władysława Łokietka na Pomorze Gdańskie w roku 1306. Księciu towarzyszył bowiem wówczas jeden z jego najwierniejszych stronników politycznych, biskup włocławski Gerward z Ostrowa, którego uważa się za głównego negocjatora układu z lokalnymi elitami, na mocy którego złożyli oni hołd Władysławowi Łokietkowi jako swojemu władcy ${ }^{81}$. Nie była to zatem typowa wyprawa zbrojna, choć w taką mogła się przerodzić. Nie wiemy też, w którym momencie ordynariusz włocławski dołączył do dworu książęcego. Nie wiadomo, czy towarzyszył księciu w Świeciu i Byszewie na przełomie listopada i grudnia ${ }^{82}$, natomiast był już z pewnością świadkiem wydarzeń, które rozegrały się w Tczewie i Gdańsku ${ }^{83}$. Oczywiście, w tym przypadku obecność biskupa przy księciu była o tyle jeszcze naturalna, że władca przemierzał ziemie należące do diecezji włocławskiej.

Dość mocno nasycone konfliktami zbrojnymi panowanie księcia, a później króla, Władysława Łokietka nie przynosi żadnych wyraźnych śladów obecności w jego armii biskupów, nawet gdy chodziło o wojnę w obronie kraju przed obcym najazdem. Nie ma jednak wątpliwości, że w czasie konfliktu z zakonem krzyżackim król polski mógł liczyć na wsparcie ze strony swojego episkopatu. Dotyczy to przede wszystkim arcybiskupa gnieźnieńskiego Janisława oraz biskupa włocławskiego Macieja z Gołańczy. Janisław był postrzegany w tym czasie przez Krzyżaków jako doradca króla, z którym uzgadniano sposoby prowadzenia wojny, w tym także militarny sojusz antykrzyżacki z poganami ${ }^{84}$. Miał on także wesprzeć w konkretny sposób działania zbrojne Władysława Łokietka

\footnotetext{
80 C. Nakashian, op. cit., szczeg. s. 183, 202-203; L. Taylor, op. cit., s. 13.

81 Proces przejmowania rządów na Pomorzu Gdańskim przez Władysława Łokietka jesienią i wczesną zimą 1306 r. wnikliwie omówił B. Śliwiński, Pomorze, s. 256-279.

82 Pommerellisches Urkundenbuch, wyd. M. Perlbach, Danzig 1882, nr 649; Kodeks dyplomatyczny Wielkopolski, t. 2, wyd. I. Zakrzewski, Poznań 1878, nr 906. Z zeznań Gerwarda na procesie inowrocławsko-brzeskim zdaje się wynikać, że był razem z księciem w Świeciu, ale nie wiadomo, czy cała wypowiedź dotyczy tego samego czasu, zob. przyp. poniżej.

83 Lites (1320), s. 25, 32; Pommerellisches, nr 650; B. Śliwiński, Pomorze, s. 267-270.

84 Lites (1339), s. 90; J. Bieniak, Wielkopolska, Kujawy, ziemie łęczycka i sieradzka wobec problemu zjednoczenia państwowego w latach 1300-1306, wyd. 2, Wodzisław Śląski 2011, s. 15.
} 
i jego syna Kazimierza w ziemi chełmińskiej w czasie wyprawy odwetowej w roku 1330, wysyłając im jakieś posiłki zbrojne ${ }^{85}$. A jako doradca królewski nadzorował również sprawę ważnego ze strategicznego punktu widzenia układu biskupa włocławskiego z Zakonem z 24 sierpnia tego samego roku, który ostatecznie był zmuszony zaakceptować ${ }^{86}$.

Drugi ze wspomnianych biskupów, ordynariusz kujawski Maciej z Gołańczy, przebywał w latach wojny Polski z Zakonem (1329-1331) na terenie swojej diecezji, która została bezpośrednio dotknięta przez działania zbrojne. Pod koniec kwietnia 1329 r. Krzyżacy złupili, nie pierwszy raz zreszta, dobra biskupie. W Niedzielę Wielkanocną został spalony stołeczny Włocławek wraz z kościołem katedralnym, a wkrótce potem miasto biskupie $w$ Raciążku ${ }^{87}$. Zagrożony osobiście biskup schronił się do królewskiego Brześcia Kujawskiego i tamże 8 maja tr. zagroził sprawcom najazdu ekskomunika, jeśli nie naprawią szkód wyrządzonych Kościołowi włocławskiemu ${ }^{88}$. Latem roku następnego Krzyżacy znowu zjawili się w Raciążku i tym razem, po ośmiu dniach oblężenia, 5 lipca, zdobyli gród biskupi, broniony przez rycerzy pod dowództwem brata biskupa Macieja, dawnego wojewody tczewskiego, Świętosława ${ }^{89}$. Zwraca uwagę, że Krzyżacy przypisywali Raciążkowi istotną rolę militarną, skoro w układzie zawartym z biskupem w sierpniu 1330 r. w Toruniu zwrócili ordynariuszowi włocławskiemu wspomniany gród pod warunkiem, że nie stanie się on bazą wypadową dla jakichkolwiek militarnych działań antykrzyżackich, w tym także podejmowanych przez biskupa i jego ludzi ${ }^{90}$. Trudno się temu żądaniu dziwić. Raciążek został bowiem solidnie przygotowany przez biskupa w roku 1330 do wojny, o czym świadczy fakt, że oprócz dużych zapasów żywności zdobywcy skonfiskowali także znajdującą się w warowni znaczną liczbę broni ręcznej i miotającej ${ }^{91}$.

85 Lites (1339), s. 90: „,...idem dominus Kazimirus rex predictus cum patre suo quondam domino Wladislao et cum subditis et vasallis domini Ianislai archiepiscopi et ecclesie Gneznensis, de consilio, assensu et mandato eiusdem archiepiscopi terram Culmensem [...] violenter intravit...".

86 Preussisches, t. 2, cz. 2, nr 703; J. Bieniak, Wielkopolska, s. 15-16.

87 S. Zajączkowski, Polska a Zakon Krzyżacki w ostatnich latach Władysława Łokietka, Lwów 1929, s. 150-152.

88 Codex diplomaticus Poloniae, t. 2, cz. 1, wyd. L. Rzyszczewski, A. Muczkowski, Varsaviae 1848, nr 249: „,...in ciuitate seu opido brestensi, ubi nunc delitescimus, de kathedra nostra per eos eiecti".

89 Kalendarz i spominki włocławskie, MPH, Nova series, t. 6, s. 83; Annales, lib. 9, [1330].

90 Codex diplomaticus Poloniae, t. 2, cz. 1, nr 252: „,...quod de castro nostro Radczens, per nos et nostros et quoslibet alios nulla dampna magistro...".

91 Kalendarz, s. 83: „In quo multi thezauri hominum diversorum, arma et baliste quam plurime sunt accepta...". 
Poza tym zamek ten, będący miejscem schronienia dla okolicznej ludności i ich dobytku, został wzmocniony, najpewniej w porozumieniu z księciem Władysławem, załogą składającą się w części z rycerzy, którzy nie byli na służbie u biskupa ${ }^{92}$. Po jego utracie hierarcha kujawski ponownie sięgnął po oręż duchowy i zwrócił się o pomoc przeciw Krzyżakom do Stolicy Apostolskiej ${ }^{93}$. Zanim jednak papież zareagował na tę skargę, biskup Maciej, w porozumieniu z księciem Władysławem Łokietkiem oraz arcybiskupem Janisławem, zawarł układ z Zakonem, dzięki któremu odzyskał Raciążek i inne swoje dobra na terytoriach kontrolowanych przez Krzyżaków ${ }^{94}$. Porażka odwetowej wyprawy Łokietka na ziemie Zakonu sprawiła, że biskup przedłożył dokument układu toruńskiego do zatwierdzenia swojemu metropolicie ${ }^{95}$.

W kontekście omawianego zagadnienia interesująca jest także obecność ordynariusza włocławskiego na polu bitwy pod Płowcami wkrótce po zakończeniu tego starcia ${ }^{96}$. Być może wspominane przez źródła liczenie i chowanie poległych zaczęło się już następnego dnia. Jednak trzeba pamiętać, że zarówno stolica diecezji we Włocławku, jak i odzyskany przez biskupa zamek w Raciążku znajdują się w odległości niewiele przekraczającej trzydzieści kilometrów od pola bitwy, więc szybkie przybycie miejscowego ordynariusza na pole śmierci ponad czterech tysięcy osób nie wywołuje wielkiego zdziwienia. Niestety, próżno snuć domysły o tym co robił biskup Maciej w samym dniu bitwy. Wattpliwe jednak, aby towarzyszył armii polskiej, w której posługi duszpasterskie sprawowali wówczas kapelani królewscy ${ }^{97}$.

Inaczej wygląda sprawa $\mathrm{w}$ odniesieniu do innego zagrożonego wojną sufragana gnieźnieńskiego. $Z$ zeznań złożonych na procesie warszawsko-uniejowskim przez biskupa poznańskiego Jana Łodzię wynika, że w czasie, gdy wojska zakonne atakowały Kujawy, ordynariusz ten cum

92 Długosz wymienia niektórych z nich z imienia, zapewne za zaginiona, szerszą wersją Spominków włocławskich, Annales, lib. 9, 146; J. Bieniak, Wielkopolska, s. 15.

93 Lites (1339), dodatek nr 16.

94 Codex diplomaticus Poloniae, t. 2, cz. 1, nr 252; J. Bieniak, Wielkopolska, s. 15 i n.

95 Preussisches, t. 2, cz. 2, nr 707.

96 Wigand von Marburg, Nowa kronika pruska, wyd. S. Zonenberg, K. Kwiatkowski, Toruń 2017, s. 184; Chronica Olivensis, s. 330.

97 Kustosz katedry krakowskiej i kapelan Łokietka Jakub Szyrzyk uczestniczył w walkach Łokietka z Krzyżakami w roku 1329 i 1331, Lites (1339), s. 387-388; J. Ptak, Duszpasterstwo, s. 87, 98. Przy czym trzeba zaznaczyć, że wiemy wyłącznie o pełnieniu przez niego posług duszpasterskich, a w działania zbrojne się nie angażował, skoro sam twierdził, że wojsko krzyżackie widział tylko a longe. W 1444 r. pod Warną brał udział kapelan i notariusz kancelarii królewskiej Grzegorz z Sanoka, późniejszy metropolita lwowski, Annales, lib. 12, s. 329. 
familia sua podążał na Mazowsze, a zatem do archidiakonatu czerskiego swojej diecezji. Co ciekawe, biskup w swoją podróż wyruszyć musiał tuż po zdobyciu Raciążka przez Krzyżaków, gdyż 6 lipca (czyli nazajutrz po poddaniu biskupiego grodu) przebywał jeszcze w Poznaniu. W drodze zaś spotykał uciekinierów z Kujaw, którzy opowiadali mu o poczynaniach krzyżackich, w tym o oblężeniu Brześcia Kujawskiego ${ }^{98}$. Z kolei z dalszej części zeznań tego hierarchy ewidentnie odnoszących się do roku 1331 i zniszczeń poczynionych przez napastników w Wielkopolsce, w tym także w dobrach biskupstwa poznańskiego, wynika, że Jan z pewnością nie brał żadnego udziału w wojnie. Dwukrotnie zresztą podkreślał, że gdy tylko widział w oddali oddział krzyżacki, zachowywał daleko idącą ostrożność i starał się jak najszybciej oddalić z miejsca, uciekając nawet do lasu, by ratować życie ${ }^{99}$. Możliwe, że o trzymaniu się z dala przez biskupa Jana od zgiełku wojennego mogły zadecydować także jego cechy charakteru. Współcześni charakteryzowali go bowiem jako człowieka dobrze wykształconego, muzykalnego, piszącego wyrafinowaną poezję religijna, a przy tym wesołego i niestroniącego od uciech cielesnych ${ }^{100}$.

Wkład militarny biskupów w obronę Królestwa Polskiego nie wypada zbyt imponująco. Zahamowanie już za Władysława Łokietka dążeń biskupów do tworzenia i rozwoju kościelnych władztw terytorialnych nie sprzyjało wzmacnianiu możliwości mobilizacyjnych oddziałów biskupich. Za to dobra kościelne i duchowni byli w zasadzie wolni od obowiązku zbrojnego wspierania monarchy, co dotyczyło oczywiście także biskupów ${ }^{101}$. Sprawy komplikowały się wszakże, gdy duchowny miał w swoim posiadaniu jakieś dobra rodowe. Statut wiślicki Kazimierza Wielkiego mówi bowiem o obowiązku osobistego stawiania się na wyprawę zbrojną takich duchownych, nie przewidując możliwości zastępstwa, a za niestawiennictwo grozi konfiskatą majątku ${ }^{102}$. Niektórzy uczeni przepis ten odnoszą już do czasów Władysława Łokietka, dając

98 Lites (1339), s. 154. Potwierdzone są pobyty bpa Jana w Poznaniu od 13 V i 6 VII, Kodeks dyplomatyczny Wielkopolski, t. 2, nr 1109-1110.

99 Lites (1339), s. 155-156; J. Maciejewski, Las jako miejsce schronienia w zeznaniach świadków procesu polsko-krzyżackiego w roku 1339, w: II Ogólnopolska Konferencja "Las w kulturze polskiej": materiaty konferencyjne, red. W. Łysiak, Poznań 2002, s. 133.

100 Kalendarz, s. 84-85.

101 Wydaje się, że kwestie te były jednak przedmiotem jakichś negocjacji. I tak dla przykładu w Wielkopolsce król starał się zachować pewne obowiązki militarne Kościoła w czasie obcego najazdu, jak o tym świadczy dyplom z 1 III 1357 r., w którym nakazano ludności dóbr kościelnych leżących w sąsiedztwie zaatakowanej okolicy stawić się na takich samych zasadach jak miejscowe rycerstwo, Kodeks dyplomatyczny Wielkopolski, t. 3, nr 1354.

102 Statuty Kazimierza Wielkiego, oprac. O. Balzer, z rękopisu pośmiertnego wyd. Z. Kaczmarczyk, M. Sczaniecki, S. Weyman, Poznań 1947, s. 45; Ostatnio K. Ginter, Udział szlachty 
przykład starań w roku 1335 późniejszego arcybiskupa gnieźnieńskiego Jarosława z Bogorii o dyspensę ze względu na irregularitas zaciągniętą z powodu udziału w jakichś zmaganiach zbrojnych. Przyczyną powstania tej przeszkody kanonicznej miałoby być właśnie wypełnianie przez tego prałata obowiązku ciążącego na jego dobrach rodowych, a jeśli nawet sam nie walczył, to był odpowiedzialny za działania ludzi, których przyprowadził ${ }^{103}$. Cytowane źródło nie daje jednak podstaw do tak daleko idących wniosków. Blisko związany z dworem królewskim i pełniący od roku 1331 urząd kanclerza kujawskiego Jarosław mógł właśnie z tego tytułu uczestniczyć w wojnach swojego monarchy, a nawet bezpośrednio $\mathrm{w}$ walce ${ }^{104}$. Istnieją zresztą istotne przesłanki, by wątpić $\mathrm{w}$ istnienie wspomnianego obciążenia już w tym czasie. Warto bowiem zauważyć, że cytowany przepis znalazł się dopiero w statucie małopolskim, w którym upatruje się próby tworzenia ustawodawstwa ogólnopolskiego ${ }^{105}$, brak go natomiast w nieco wcześniejszym statucie wielkopolskim. Co więcej, w roku 1359 biskup krakowski Bodzęta z Wrześni, na prośby króla Kazimierza, ogłosił ordynację, w której zawarł bardzo podobne rozporządzenie dla duchowieństwa ${ }^{106}$. Może to świadczyć o tym, że mamy tu do czynienia z wynegocjowaną między królem a biskupem umową która, według Jana Długosza, miała nawet kończyć jakieś społeczne niepokoje ${ }^{107}$. Sprawa mogła być więc dyskutowana od dłuższego czasu. Przyjęte rozwiązania dawały pierwszeństwo prawu rycerskiemu (świeckiemu) nad kanonicznym, lecz Kościół krakowski jednak je poparł, więc może słuszny

polskiej w pospolitym ruszeniu w XIV i XV wieku. Aspekty prawne i stan faktyczny, Kraków 2008, s. 74-77, 178-179, gdzie cytowana starsza literatura.

103 Kodeks dyplomatyczny Wielkopolski, t. 2, nr 1151; J. Bieniak, Geneza procesu polsko-krzyżackiego z 1339 roku, „Acta Universitatis Nicolai Copernici. Nauki Humanistyczno-Społeczne. Historia" 1990, 24, 204, s. 38; J. Ptak, Duszpasterstwo, s. 104.

104 J. Bieniak, List kanclerza kujawskiego do rady starego miasta Torunia ze stycznia 1331 roku, „Zapiski Kujawsko-Dobrzyńskie. Seria A, Historia” 1978, s. 125; J. Tęgowski, Kanclerz kujawski Jarosław Bogoria i jego stosunki z Galhardem de Carceribus, w: Personae, colligationes, facta, red. J. Bieniak et al., Toruń [1991], s. 41. J. Ptak, Duszpasterstwo, s. 105 wskazuje właśnie na kapelanów jako na grupę duchownych, która włączała się z pewnością niejednokrotnie do walki z nieprzyjacielem.

105 Upowszechnienie monarszego prawa stanowionego było w Polsce długim procesem, który przypadł głównie na czasy Jagiellonów, J. Kurtyka, Odrodzone królestwo. Monarchia Władysława Łokietka i Kazimierza Wielkiego w świetle nowszych badań, Kraków 2001, s. 164, gdzie cytowana starsza literatura.

106 Ius Polonicum, wyd. J.V. Bandkie, Varsoviae 1831, s. 167: „Clerici vero cujuscunque status, vel conditionis existant, bona patrimonialia possidentes, ad expeditionem cum domino rego transeant".

107 Annales, lib. 9, s. 293; K. Ginter, op. cit., s. 76-77. 
jest pogląd, że chodziło o kompromis, gdyż początkowo oczekiwano, że biskupstwo to będzie partycypowało w większym stopniu w wojskowości, również jako instytucja ${ }^{108}$. Można zatem wątpić, czy statut czternasty ordynacji wiślickiej wszedł w życie w całej rozciągłości w czasach Kazimierza Wielkiego, szczególnie poza Małopolską. Tym bardziej że jeszcze w początkach XV w. nie do końca go przestrzegano, w każdym razie $\mathrm{w}$ odniesieniu do biskupów. Monarcha mógł oczywiście liczyć na specjalne wsparcie militarne, ale przede wszystkim ze strony tych hierarchów, którzy wspierali aktualną linię jego polityki. Cytowana powyżej informacja o wspomaganiu militarnym Łokietka przez arcybiskupa Janisława w wyprawie na ziemię chełmińską może wspierać taki właśnie tok rozumowania. Innym dobrym przykładem jest postawa zaprezentowana w roku 1410 przez biskupa poznańskiego Wojciecha Jastrzębca oraz arcybiskupa gnieźnieńskiego Mikołaja z Kurowa, którzy choć nie brali osobiście udziału w zmaganiach wojennych, to wsparli króla, wystawiwszy z funduszy prywatnych dwie chorągwie, które walczyły pod Grunwaldem ${ }^{109}$.

Wydaje się, że Kazimierz Wielki oczekiwał raczej materialnego wsparcia Kościoła niż osobistego stawiennictwa duchownych. Taką linię polityki królewskiej w tej sprawie można wyczytać z dokumentu ugody króla z biskupem krakowskim z roku 1354, gdy za sumę 500 grzywien groszy ordynariusz wykupił wojskowe powinności dwóch kasztelanii biskupich, tarskiej i kieleckiej, które nakładał na nich dokument Bolesława Wstydliwego w wypadku najazdu Litwinów ${ }^{110}$. Król Kazimierz niejednokrotnie zwracał się również do biskupów lub papieża o specjalne wsparcie pieniężne, czy to w postaci nadzwyczajnej daniny (subsidium charitativum), czy też przejęcia płaconych przez kler dziesięcin papieskich, a w przypadku poważniejszych przedsięwzięć wojennych zaciągał także pożyczki, między innymi w postaci przejmowania - za zgodą biskupów - klejnotów kościelnych ${ }^{111}$. Wzajemne relacje dworu królewskiego z Kościołem $w$ kontekście wsparcia militarnego monarchy przez kler celnie podsumowuje Janek z Czarnkowa, opisując reakcję biskupów i kapituł na prośbę skierowaną do nich przez króla Ludwika o przysłanie mu zbrojnej

108 K. Ginter, op. cit., s. 77-78, choć pogląd autora, że sprawa statutu miała swoje źródło w niechęci króla do biskupa Bodzęty, wydaje się daleki od prawdy, a raczej chodzi tu o typową dla króla Kazimierza postawę pragmatyczną.

109 K. Mosingiewicz, op. cit., s. 118-120; S. Szybkowski, op. cit., szczeg. s. 210-211, 220221, 225.

110 KKK, t. 1, nr 198-199; M. Niwiński, Biskup krakowski Bodzanta i Kazimierz Wielki, „Collectanea Theologica" 1936, 17, 1-2, s. 250.

111 S.M. Kuczyński, Polskie siły zbrojne za Kazimierza Wielkiego i Andegawenów, „Studia i Materiały do Historii Wojskowości" 1965, 11, 2, s. 13, 29. 
pomocy na wyprawę litewską. Prałaci mieli odpowiedzieć wówczas królowi, że mogą go wesprzeć tylko pieniężnie i zagrozić karami kościelnymi tym, którzy nie zechcą zapłacić, zbrojnych bowiem „episcopi et capitula minime habebant"112.

Nawet późniejsze, już piętnastowieczne przekazy źródłowe, a zatem z czasów, gdy zmieniły się relacje między episkopatem a dworem, a biskupi ponownie kierowali kancelarią królewską ${ }^{113}$, potwierdzają obecność biskupów w wojsku monarchów jagiellońskich jedynie w odniesieniu do wstępnych etapów kampanii wojennych, takich jak narady wojenne, koncentracja wojsk czy uroczystości religijne przed wyruszeniem na wojnę. W związku z wojną powierzano także hierarchom specjalne zadania dyplomatyczne lub administracyjne, podobnie jak biskupom węgierskim w roku 1241. I tak arcybiskup Mikołaj Kurowski miał w czasie wyprawy polsko-litewskiej do Prus w lecie roku 1410 pieczę nad zamkiem w Krakowie, gdzie sprawował funkcję królewskiego namiestnika ${ }^{114}$, natomiast $\mathrm{w}$ roku poprzednim starał się $\mathrm{z}$ polecenia władcy zapośredniczyć rozejm z Krzyżakami pod obleganymi przez nich Bobrownikami, obiecując przy tym załodze broniącej zamku, że nadejdzie pomoc ${ }^{115}$. Z kolei w czasie wspomnianej wyprawy pruskiej armii polskiej towarzyszyło przez pewien czas dwóch biskupów ${ }^{116}$. Jakub z Korzkwi, jako ordynariusz miejsca, odprawił w klasztorze w Czerwińsku mszę dla całego wojska oraz wygłosił tam kazanie o wojnie sprawiedliwej, zachęcając zgromadzonych wojowników do walki117. Dłużej przebywał przy królu biskup poznański Wojciech Jastrzębiec, który przyprowadził też wystawioną własnym sumptem chorągiew prywatna, a któremu monarcha pozwolił odjechać do domu zanim zaczęły się właściwe działania zbrojne ${ }^{118}$. Wrócił on jednak do armii po otrzymaniu listu od Jagiełły o zwycięstwie i towarzyszył

112 Kronika Jana z Czarnkowa, wyd. J. Szlachtowski, MPH, t. 2, s. 678. Wg Annales, lib. 10,

s. 56, biskupi odmówili królowi w ogóle wsparcia, nawet pieniężnego.

113 T. Graff, op. cit., s. 74.

114 Annales, lib. 11, s. 59.

115 S.M. Kuczyński, Wielka wojna z Zakonem Krzyżackim w latach 1409-1411, Warszawa 1980, s. 133-134, przyp. 66.

116 J. Ptak, Duszpasterstwo, s. 98-99. Nie ma racji Jerzy Sójka, op. cit., s. 102, który obecnego pod Grunwaldem podkanclerzego Mikołaja Trąbę nazywa biskupem. Po pierwsze wątpliwe, aby Mikołaj dowiedział się już o nominacji papieskiej na arcybiskupstwo lwowskie, która miała miejsce 17 VI 1410 r., a ponadto jeszcze w grudniu tego roku nie miał święceń biskupich, Bullarium Poloniae, t. 3, wyd. I. Sułkowska-Kuraś, S. Kuraś, Rzym 1988, nr 1261, 1280.

117 Annales, lib. 11, s. 65.

118 Ibidem, s. 70; G. Lichończak-Nurek, Wojciech herbu Jastrzębiec, arcybiskup i mą̇̇ stanu (ok. 1362-1436), Kraków 1996, s. 34-35. 
przez pewien czas monarsze $\mathrm{w}$ czasie oblężenia Malborka, zanim nie został odprawiony ze względu na chorobę ${ }^{119}$. Można więc odnieść wrażenie, że biskupów starano nie narażać na niebezpieczeństwa wojenne.

W kolejnych dziesięcioleciach nie widać znaczących zmian. W następnej wyprawie zbrojnej Jagiełły do Prus uczestniczyli bowiem biskupi, mianowicie metropolita Mikołaj Trąba i jego sufragani z Płocka i Krakowa, ale do działań zbrojnych w ogóle nie doszło, a armia polska nie przekroczyła krzyżackiej granicy. Przedłużono tylko rozejm z Krzyżakami, który zagwarantowali także wspomniani polscy ordynariusze ${ }^{120}$. Tych samych członków episkopatu spotykamy trzy lata później przy królu w obozie armii królewskiej pod Czerwińskiem, a zatem towarzyszyli ponownie armii ciągnącej przeciwko Krzyżakom ${ }^{121}$. Niektórzy badacze sądza, że jeden $\mathrm{z}$ nich, Wojciech Jastrzębiec, pozostał z monarchą przez cały czas kampanii roku $1422^{122}$. Obecność tę dałoby się zresztą dość łatwo wytłumaczyć pełnieniem przez biskupa krakowskiego w tym czasie urzędu kanclerskiego. Wątpliwości musi budzić jednak to, że pogląd o obecności kanclerza przy królu w trakcie działań wojennych jest oparty wyłącznie na dokumentach, na których imię biskupa pojawia się jedynie w formule datum per manus ${ }^{123}$. Tymczasem formuła ta wówczas pełniła już tylko rolę ozdobnika, nieoznaczającego praktycznego udziału w przygotowywaniu dokumentów, a zatem nie może potwierdzać obecności kanclerza w danym miejscu w momencie zaistnienia czynności prawnej ${ }^{124}$.

Za niezwykle charakterystyczne $\mathrm{w}$ tym kontekście można uznać zatem zachowanie biskupa krakowskiego Zbigniewa Oleśnickiego w czasie wyprawy w roku 1431 przeciwko księciu Świdrygielle. Ordynariusz

119 Dopetnienie szamotulskie, wyd. A. Bielowski, MPH, t. 2, s. 865-867; Annales, lib. 11, s. 132; G. Lichończak-Nurek, op. cit., s. 35-36.

120 Kodex dyplomatyczny Litwy, wyd. E. Raczyński, Wrocław 1845, nr 7, s. 250-251. T. Silnicki, Arcybiskup Mikołaj Trąba, Warszawa 1954, s. 192; J. Sójka, op. cit., s. 103; G. Lichończak-Nurek, op. cit., s. 73-77, 257.

121 Volumina legum, t. 1, wyd. J. Ohryzko, Petersburg 1859, kol. 82-85.

122 J. Sójka, op. cit., s. 103. G. Lichończak-Nurek, op. cit., s. 88-89, twierdzi, że biskup krakowski pozostawał ciągle przy królu od początku czerwca do końca września $1422 \mathrm{r}$.

${ }^{123}$ Zbiór dokumentów małopolskich, t. 7, wyd. S. Kuraś, I. Sułkowska-Kuraś, Wrocław 1975, nr 1927; Codex diplomaticus Poloniae, t. 1, nr 169; Codex diplomaticus Regni Poloniae et Magnus Ducatus Lithuaniae, t. 4, wyd. M. Dogiel, Wilno 1764, nr 90.

124 S. Kętrzyński, Zarys nauki o dokumencie polskim wieków średnich, Warszawa 1934, s. 360; I. Sułkowska-Kuraś, Polska kancelaria królewska w latach 1447-1506, Wrocław 1967, s. 60 i n.; eadem, Dokumenty królewskie i ich funkcja w państwie polskim za Andegawenów i pierwszych Jagiellonów, Warszawa 1977, s. 111 i n. Wspomniany w tej formule w obu dokumentach z 27 września podkanclerzy Jan Szafraniec jeszcze dziesięć dni wcześniej brał udział w posiedzeniu kapituły katedralnej w Krakowie, KKK, t. 2, nr 611. 
krakowski odprowadził bowiem armię nad rzekę Bug, udzielił jej błogosławieństwa, a następnie powrócił do swojej stolicy ${ }^{125}$.

\section{KONKLUZJE}

Biskupi obowiązek służenia władcy na wojnie podlegał $\mathrm{w}$ Polsce w XIII i XIV w. znaczącym przemianom i był kwestią ciągłych negocjacji, na które największy wpływ miały aktualne stosunki lokalnego Kościoła $\mathrm{z}$ władcą. Biskupi w okresie dzielnicowym, mniej więcej od najazdu tatarskiego w roku 1241, nie uczestniczyli w wyprawach zbrojnych władców piastowskich, co było konsekwencją upadku władzy centralnej oraz zwycięskich dla Kościoła zmagań o wolności kościelne, czyli inaczej mówiąc rozmontowaniu systemu kościoła państwowego. W okresie zjednoczeniowym pojawiły się co prawda wyraźne tendencje do zmiany tego nastawienia, ale nie zaowocowało to militaryzacją episkopatu choćby na podobieństwo takich krajów jak Węgry czy Czechy, nie mówiąc już o Rzeszy, głównie ze względów ustrojowych. Co prawda wraz z odrodzeniem ogólnopolskiej monarchii piastowskiej biskupstwa i ich zwierzchnicy zostali ponownie włączani w sferę działalności państwowej, ale ani władcy, jak się zdaje, nie nalegali na osobiste zaangażowanie zbrojne hierarchów, ani ci drudzy z własnej woli nie wykazywali większego zainteresowania rzemiosłem wojennym. A taka postawa mogła być konsekwencją zmiany norm kulturowych i oczekiwań społecznych wśród elit późnośredniowiecznego Królestwa Polskiego.

$\mathrm{Z}$ tego powodu kompetencje militarne biskupów polskich w późnym średniowieczu zdają się być już mocno ograniczone, a królowie polscy oczekiwali od episkopatu raczej wsparcia materialnego niż osobistego uczestniczenia w kampanii wojennej. Jeżeli nawet któryś z biskupów wyruszał na wojnę wraz z armią królewska, to uczestniczył jedynie we wczesnych fazach wyprawy, sprawując funkcje duszpasterskie, a następnie, zapewne by nie narażać życia na niebezpieczeństwa wojenne, usuwał się $\mathrm{w}$ bezpieczne miejsce lub wracał do domu. Zdecydowanie nie było wśród episkopatu polskiego tych czasów wojowników, którzy uczestniczyliby z bronią w ręku w zmaganiach zbrojnych. Nie czynili tak nawet wówczas, gdy dostarczali królowi posiłki zbrojne opłacone ze swoich dóbr prywatnych.

125 Annales, lib. 11, s. 26; J. Ptak, Duszpasterstwo, s. 99. 


\section{REFERENCES (BIBLIOGRAFIA)}

\section{Printed sources (Źródła drukowane)}

Annales Reinhardsbrunnenses, wyd. F.X. Wegele, Thüringische Geschichtsquellen, t. 1, Jena 1854.

Annales Posonienses, Scriptores Rerum Hungaricarum, t. 1, wyd. E. Szentpétery, Budapestini 1937.

Bullarium Poloniae, t. 3, wyd. I. Sułkowska-Kuraś, S. Kuraś, Rzym 1988.

Canonicorum Pragensium continuationes Cosmae, wyd. D.R. Köpke, Monumenta Germaniae Historica Scriptores, t. 9, Hannoverae 1851.

Chronica de Gestis Hungarorum e Codice Picto Saec. XIV, wyd. i tłum. J.M. Bak, L. Veszprémy, Budapest-New York 2018.

Chronica Poloniae Maioris, wyd. B. Kürbis, Monumenta Poloniae Historica, Nova series, t. 8, Warszawa 1970.

Chronica Polonorum, wyd. L. Ćwikliński, Monumenta Poloniae Historica, t. 3, Lwów 1878.

Chronicon Aulae Regiae, wyd. J. Emler, Fontes Rerum Bohemicarum, t. 4, Praga 1884.

Codex diplomaticus et commemorationum Masoviae generalis, wyd. J.K. Kochanowski, Warszawa 1919.

Codex diplomaticus Regni Poloniae et Magnus Ducatus Lithuaniae, t. 4, wyd. M. Dogiel, Wilno 1764.

Codex diplomaticus Poloniae, t. 1-2, wyd. L. Rzyszczewski, A. Muczkowski, Varsaviae 18471848.

Codex diplomaticus Silesiae, t. 16, wyd. C. Grünhagen, K. Wuttke, Breslau 1892.

Codex epistolaris saeculi decimi quinti, t. 2, wyd. A. Lewicki, Kraków 1891.

Corpus iuris canonici, t. 1, Decretum magistri Gratiani, wyd. E. Friedberg, wyd. 2, Graz 1959.

Cosmae Pragensis Chronica Boemorum, wyd. B. Bretholz, Monumenta Germaniae Historica, Scriptores Rerum Germanicarum, Nova series, t. 2, Berolini 1923.

Dopetnienie szamotulskie, wyd. A. Bielowski, Monumenta Poloniae Historica, t. 2, Lwów 1872.

Exordium ordinis cruciferorum seu Chronica de Prussia, wyd. W. Kętrzyński, Monumenta Poloniae Historica, t. 6, Kraków 1893.

Historia compostelana, tłum. E. Falque, Madrid 1994.

Ius Polonicum, wyd. J.V. Bandkie, Varsoviae 1831.

Joannis Dlugossi Annales seu cronicae incliti Regni Poloniae, lib. 1-12, wyd. consilium, Varsaviae-Cracoviae 1964-2005.

Kalendarz i spominki włocławskie, wyd. B. Kürbis, Monumenta Poloniae Historica, Nova series, t. 6, Warszawa 1962.

Katalogi biskupów krakowskich, wyd. J. Szymański, Monumenta Poloniae Historica, Nova series, t. 10, cz. 2, Warszawa 1974.

Kodeks dyplomatyczny katedry krakowskiej św. Wacława, t. 1-2, wyd. F. Piekosiński, Kraków 1874-1883.

Kodeks dyplomatyczny Wielkopolski, t. 2-3, wyd. I. Zakrzewski, Poznań 1878-1879.

Kodeks dyplomatyczny Wielkopolski, t. 6, wyd. A. Gąsiorowski, H. Kowalewicz, Poznań 1982.

Kodex dyplomatyczny Litwy, wyd. E. Raczyński, Wrocław 1845.

Kronika Halicko-Wołyńska (Kronika Romanowiczów), wyd. D. Dąbrowski, A. Jusupović, Monumenta Poloniae Historica, Nova series, t. 16, Kraków-Warszawa 2017.

Kronika Jana z Czarnkowa, wyd. J. Szlachtowski, Monumenta Poloniae Historica, t. 2, Lwów 1872. 
Latopis kijowski, cz. 1, tłum. E. Goranin, Wrocław 1995.

Lites ac res gestae inter Polonos Ordinemque Cruciferorum, t. 1, wyd. I. Zakrzewski, Posnaniae 1890.

Lites ac res gestae inter Polonos Ordinemque Cruciferorum, t. 1, Causa Junivladislaviae et Brestiae-Cuiaviae anno 1320-1321 acta, wyd. H. Chłopocka, Wrocław-Warszawa-Kraków 1970.

Magistri Rogeri Epistola in miserabile carmen super destructione regni Hungariae per Tartaros facta, tłum. i komentarz J.M. Bak, M. Rady, Central European Medieval Texts, 5, Budapest-New York 2010.

Magistri Vincentii dicti Kadłubek Chronica Polonorum, wyd. M. Plezia, Monumenta Poloniae Historica, Nova series, t. 11, Kraków 1994.

Monumenta Poloniae Vaticana, t. 3, wyd. J. Ptaśnik, Cracoviae 1914.

Petri de Dusburg Chronicon terrae Prussiae, wyd. M. Töppen, Lipsiae 1861.

Pommerellisches Urkundenbuch, wyd. M. Perlbach, Danzig 1882.

Powieść minionych lat, tłum. F. Sielicki, Wrocław-Warszawa-Kraków 1999.

Preussisches Urkundenbuch, t. 1-2, wyd. R. Philippi et al., Königsberg 1882-1939.

Rocznik górnoślaski, wyd. A. Bielowski, Monumenta Poloniae Historica, t. 3, Lwów 1878.

Rocznik kapituły gnieźnieńskiej, wyd. B. Kürbis, Monumenta Poloniae Historica, Nova series, t. 6, Warszawa 1962.

Rocznik kapituły krakowskiej, wyd. Z. Kozłowska-Budkowa, Monumenta Poloniae Historica, Nova series, t. 5, Warszawa 1978.

Rocznik kapituły poznańskiej, wyd. B. Kürbis, Monumenta Poloniae Historica, Nova series, t. 6, Warszawa 1962.

Rocznik kujawski, wyd. A. Bielowski, Monumenta Poloniae Historica, t. 3, Lwów 1878. Rocznik małopolski, wyd. A. Bielowski, Monumenta Poloniae Historica, t. 3, Lwów 1878. Rocznik Sędziwoja, wyd. A. Bielowski, Monumenta Poloniae Historica, t. 2, Lwów 1872.

Rocznik Traski, wyd. A. Bielowski, Monumenta Poloniae Historica, t. 2, Lwów 1872.

Statuty Kazimierza Wielkiego, oprac. O. Balzer, z rękopisu pośmiertnego wyd. Z. Kaczmarczyk, M. Sczaniecki, S. Weyman, Poznań 1947.

Thomae archidiaconi Spalatensis Historia Salonitanorum atque Spalatinorum pontificum, wyd. łac. O. Perić, tłum. i komentarz D. Karbić, M. Matijević Sokol, J.R. Sweeney, Central European Medieval Texts, 4, Budapest-New York 2006.

Vetera Monumenta Historica Hungariam Sacram Illustrantia, t. 1, wyd. A. Theiner, Romae 1859.

Vetera Monumenta Poloniae et Lithuaniae, t. 1, wyd. A. Theiner, Romae 1860.

Volumina legum, t. 1, wyd. J. Ohryzko, Petersburg 1859.

Wigand von Marburg, Nowa kronika pruska, wyd. S. Zonenberg, K. Kwiatkowski, Toruń 2017.

Zbiór dokumentów małopolskich, t. 7, wyd. S. Kuraś, I. Sułkowska-Kuraś, Wrocław 1975.

\section{Studies (Opracowania)}

Abraham W., Sprawa Muskaty, Kraków 1893.

Althoff G., Satisfaction. Peculiarities of the Amicable Settlement of Conflicts in the Middle Ages, w: Ordering Medieval Society: Perspectives on Intellectual and Practical Modes of Shaping Social Relations, red. B. Jussen, Philadelphia 2001.

Arnold B., Medieval German Bishops and their Military Retinues in the Medieval Empire, "German History" 1989, 7, 2.

Arranz Guzmán A., Cuando el clérigo va a la Guerra: algunos ejemplos de obispos "peleadores”, w: Guerra y paz en la Edad Media, red. A. Arranz Guzmán, M. del Pilar Rábade Obradó, Ó. Villarroel Gonzáles, Madrid 2013. 
de Ayala Martínez C., The Episcopate and Reconquest in the Times of Alfonso VII of Castile and León, w: Between Sword and Prayer Warfare and Medieval Clergy in Cultural Perspective, red. R. Kotecki, J. Maciejewski, J.S. Ott, Leiden-Boston 2018.

Bachrach D.S., Religion and the Conduct of War, c.300-c.1215, Woodbridge 2003.

Bagge S., From Viking Stronghold to Christian Kingdom: State Formation in Norway, c. 9001350, Copenhagen 2010.

Baldwin J., The Government of Philip Augustus. Foundations of French Royal Power in the Middle Ages, Berkeley-Los Angeles-Oxford 1986.

Banaszkiewicz J., Potrójne zwycięstwo Mazowszan nad Pomorzanami - Gall II, 49 - czyli historyk między "rzeczywistościa prawdziwa" a schematem porzadkującym, w: Kultura średniowieczna i staropolska. Studia ofiarowane Aleksandrowi Gieysztorowi w pięćdziesiąta rocznice pracy naukowej, red. D. Gawinowa et al., Warszawa 1991.

Banaszkiewicz J., Rocznik tzw. małopolski (minorycki) z początku XIV wieku - próba dookreślenia zabytku, w: Przeszłość w kulturze średniowiecznej Polski, t. 1, red. J. Banaszkiewicz, A. Dąbrówka, P. Węcowski, Warszawa 2018.

Barabás G., Thirtheenth Century Hungarian Prelates at War, w: Between Sword and Prayer Warfare and Medieval Clergy in Cultural Perspective, red. R. Kotecki, J. Maciejewski, J.S. Ott, Leiden-Boston 2018.

Baran-Kozłowski W., Arcybiskup gnieźnieński Henryk Kietlicz. Działalność kościelna i polityczna, Poznań 2005.

Barciak A., Biskup ołomuniecki Bruno z Schauenburga a Polska, „Śląski Kwartalnik Historyczny Sobótka", 1981, 36, 1.

Benson R.L., The Obligations of Bishops with "Regalia": Canonistic Views from Gratian to the Early Fifteenth Century, w: Proceedings of the Second International Congress of Medieval Canon Law, red. S. Kuttner, J.J. Ryan, Città del Vaticano 1965.

Bieniak J., Geneza procesu polsko-krzyżackiego z 1339 roku, „Acta Universitatis Nicolai Copernici. Nauki Humanistyczno-Społeczne. Historia" 1990, 24, 204.

Bieniak J., List kanclerza kujawskiego do rady starego miasta Torunia ze stycznia 1331 roku, „Zapiski Kujawsko-Dobrzyńskie. Seria A, Historia" 1978.

Bieniak J., Polityczne okoliczności śmierci księcia Leszka Białego, w: Gasawa w pamięci historycznej. W zwiazku z 620. rocznica lokacji miasta, red. D. Karczewski, Inowrocław 2009.

Bieniak J., Wielkopolska, Kujawy, ziemie łęczycka i sieradzka wobec problemu zjednoczenia państwowego w latach 1300-1306, wyd. 2, Wodzisław Śląski 2011.

Bogacki M., Przemiany w wojskowości polskiej od połowy X wieku do 1138 roku. Kształt i organizacja armii, Torun 2007.

Bührer-Thiery G., Des érêques sur la frontiére. Christianisation et sociétés de frontiére sur les marches du monde germanique aux Xe-XIe siècle, "Questiones Maedii Aevii Novae" 16, 2011.

Dąbrowski D., Król Rusi Daniel Romanowicz. O ruskiej rodzinie książęcej, społeczeństwie i kulturze w XIII w., Kraków 2016.

Dąbrowski J., Obowiazek obrony kraju w XI-XIII wieku, „Sprawozdania z Czynności i Posiedzeń Polskiej Akademii Umiejętności" 1951, 52, 10.

Dennis C., "De clericis qui pugnaverunt, aut pugnandi gratia armati fuerunt". Bishop Geoffrey of Coutances (1048-1093) and Clerical Participation in the Battle of Hastings, w: Between Sword and Prayer. Warfare and Medieval Clergy in Cultural Perspective, red. R. Kotecki, J. Maciejewski, J.S. Ott, Leiden-Boston 2018.

Deptuła C., Biskup i władca. Z problematyki ideologii państwowej i świadomości narodowej polskiego średniowiecza, „Więź” 1968, 11, 9. 
Dorronzoro Ramírez P., The Aragonese Episcopate and the Military Campaigns of Alfonso I the Battler against Iberian Muslim, w: Between Sword and Prayer. Warfare and Medieval Clergy in Cultural Perspective, red. R. Kotecki, J. Maciejewski, J.S. Ott, Leiden-Boston 2018.

Dowiat J., Kilka uwag o słownictwie Galla Anonima w zwiazku z zagadnieniem organizacji sit zbrojnych za Bolestawa Krzywoustego, „Kwartalnik Historyczny” 1959, 66, 1.

Drelicharz W., Annalistyka małopolska XIII-XV wieku. Kierunki rozwoju roczników kompilowanych, Kraków 2003.

Duggan L.G., Armsbearing and the Clergy in the History and Canon Law of Western Christianity, Woodbridge 2013.

Dygo M., Początki i budowa władztwa zakonu krzyżackiego (1226-1309), w: Państwo zakonu krzyżackiego w Prusach. Władza i społeczeństwo, red. M. Biskup, R. Czaja, Warszawa 2008.

Friedberg M., Klientela świecka biskupa krakowskiego w w. XII-XIV. Ze studiów nad organizacja społeczeństwa w Polsce średniowiecznej, Kraków 1938.

Gajek J.S., Teodozjusz Grek i jego "Słowo o wierze chrześcijańskiej i łacińskiej”, w: Teologia i kultura duchowa starej Rusi, red. W. Hryniewicz, J.S. Gajek, Lublin 1993.

Gawlas S., Człowiek uwikłany w wielkie procesy - przykład Muskaty, w: Człowiek w społeczeństwie średniowiecznym, red. R. Michałowski et al., Warszawa 1997.

Gawlas S., O kształt zjednoczonego królestwa. Niemieckie władztwo terytorialne a geneza społecznoustrojowej odrębności Polski, Warszawa 1996.

Gawron J., Czarna legenda biskupa krakowskiego Pawła z Przemankowa, „Annales Universitatis Mariae Curie-Skłodowska. Sectio F, Historia" 2016, 71.

Gerrard D., The Church at War: The Military Activities of Bishops, Abbots, and Other Clergy in England, c. 900-1200, Abingdon-New York 2016.

Ginter K., Udziat szlachty polskiej w pospolitym ruszeniu w XIV i XV wieku. Aspekty prawne i stan faktyczny, Kraków 2008.

Gładysz M., Zapomniani krzyżowcy. Polska wobec ruchu krucjatowego w XII-XIII wieku, Warszawa 2002.

Górski S., Biskupi i krzyże. Tak zwany epizod szczeciński krucjaty połabskiej (1147) w relacji Wincentego z Pragi, "Zapiski Historyczne” 2018, 83, 3.

Grabski A.F., Polska sztuka wojenna w okresie wczesnofeudalnym, Warszawa 1959.

Graff T., Episkopat monarchii jagiellońskiej w dobie soborów powszechnych XV wieku, Kraków 2008.

von Güttner Sporzyński D., Poland, Holy War, and the Piast Monarchy (1100-1230), Turnhout 2014.

Hamilton S., Church and People in the Medieval West, 900-1200, London 2013.

Hoffmann H., Der König und seine Bischöfe in Frankreich und im Deutschen Reich 936-1060, w: Bischof Burchard von Worms 1000-1025, red. W. Hartmann, Mainz 2000.

Hoffmann P., Heinrich von Würben, Bischof von Breslau, Breslau 1904.

Holtzmann W., Krone und Kirche in Norwegen im 12. Jahrhundert (Englische Analekten III), „Deutsches Archiv für Geschichte des Mittelalters” 1938, 2.

Jasiński T., Trzy nieznane oryginalne bulle Grzegorza IX dotyczace misji pruskiej z lat 1232-1234, "Zapiski Historyczne" 1988, 53, 3-4.

Jasiński T., Stosunki ślasko-pruskie i śląsko-krzyżackie w pierwszej połowie XIII w, w: „Ars historica". Prace z dziejów powszechnych i Polski, red. M. Biskup, H. Łowmiański, Poznań 1976.

Jensen K.V., Bishops on Crusade, w: Dominus Episcopus. Medieval Bishops Between Diocese and Court, red. A.J. Lappin, E. Balzamo, Stockholm 2018. 
Jusupović A., Pieczętnik a tysięcznik. Kariera Cyryla pieczętnika, późniejszego metropolity w XIII-wiecznej Rusi, „Przegląd Wschodni” 2017, 14, 3.

Karasiewicz W., Paweł z Przemankowa biskup krakowski 1266-1292, „Nasza Przeszłość” 1956, 9.

Kętrzyński S., Zarys nauki o dokumencie polskim wieków średnich, Warszawa 1934.

Komaniecka M., Działalność polityczna arcybiskupa Janisława, „Nasza Przeszłość” 2005, 103.

Kotecki R., Aleksander z Malonne - "persona mixta”. Wojowniczy biskup na krańcach chrześcijańskiego świata i jego kronikarski portret, „Studia Źródłoznawcze” 2017, 55.

Kotecki R., Lions and Lambs, Wolves and Pastors of the Flock: Portraying Military Activity of Bishops in Twelfth-Century Poland, w: Between Sword and Prayer. Warfare and Medieval Clergy in Cultural Perspective, red. R. Kotecki, J. Maciejewski, J.S. Ott, Leiden-Boston 2018.

Kotecki R., Ordynariusz płocki Szymon w Gallowej narracji o bitwie Mazowszan z Pomorzanami, w: Ecclesia et bellum. Kościół wobec wojny i zaangażowania militarnego duchowieństwa w wiekach średnich, red. R. Kotecki, J. Maciejewski, Bydgoszcz 2016.

Kotecki R., With the Sword of Prayer, or How Medieval Bishop Should Fight, "Quaestiones Medii Aevi Novae" 2016, 21.

Kotecki R., Maciejewski J., Writing Episcopal Courage in Twelfth-Century Poland: Gallus Anonymous and Master Vincentius, w: In the Hands of God's Servants' III: The Power of the Bishop and the Problem of Personality, red. P.R. Coss et al., Turnhout 2020.

Kucharski W., "Beatus Ceslaus natione Polonus”. Dzieje kultu błogosławionego Czesława, Kraków 2012.

Kuczyński S.M., Polskie sity zbrojne za Kazimierza Wielkiego i Andegawenów, „Studia i Materiały do Historii Wojskowości" 1965, 11, 2.

Kuczyński S.M., Wielka wojna z Zakonem Krzyżackim w latach 1409-1411, Warszawa 1980.

Kurtyka J., Odrodzone królestwo. Monarchia Władysława Łokietka i Kazimierza Wielkiego w świetle nowszych badań, Kraków 2001.

Kürbis B., „Pollexianorum cervicosa feritas”. Dzikość i barbarzyństwo w opinii Mistrza Wincentego, w: Słowianie w dziejach Europy, red. J. Ochmański, Poznań 1974.

Kwiatkowski S., Powstanie i kształtowanie się chrześcijańskiej mentalności religijnej w Polsce do końca XIII w., Warszawa 1980.

Labuda G., O katalogach biskupów krakowskich przed Długoszem, "Studia Źródłoznawcze” 1983, 27.

Labuda G., Zaginiona kronika w „Rocznikach” Jana Długosza, Poznań 1983.

Libor J., Václav II. Král na stř́brném trưnu 1283-1305, Praha 2015.

Lichończak-Nurek G., Wojciech herbu Jastrzębiec, arcybiskup i mąż stanu (ok. 1362-1436), Kraków 1996.

Lincoln K.C., Beating Swords into Croziers: Warrior Bishops in the Kingdom of Castile, c. 11581214, "Journal of Medieval History" 2017, 44, 1.

Lund N., The Military Obligations of the Danish Church in the High Middle Ages, w: The Medieval Way of War: Studies in Medieval Military History in Honor of Bernard S. Bachrach, red. G.I. Halfond, Farnham-Burlington 2015.

Łaguna S., Dwie elekcje, [1878], w: Pisma Stosława Łaguny, wyd. J. Bieliński, Warszawa 1915.

Maciejewski J., A Bishop Defends His City or Master Vincentius's Troubles with the Military Activity of His Superior, w: Between Sword and Prayer Warfare and Medieval Clergy in Cultural Perspective, red. R. Kotecki, J. Maciejewski, J.S. Ott, Leiden-Boston 2018.

Maciejewski J., Biskup krakowski Pełka a bitwa nad Mozgawa w 1195 roku, „Kwartalnik Historyczny" 2018, 124, 3.

Maciejewski J., Episkopat polski doby dzielnicowej 1180-1320, Kraków-Bydgoszcz 2003. 
Maciejewski J., Las jako miejsce schronienia w zeznaniach świadków procesu polsko-krzyżackiego w roku 1339, w: II Ogólnopolska Konferencja „Las w kulturze polskiej”: materiały konferencyjne, red. W. Łysiak, Poznań 2002.

Maciejewski J., Making War and Enormities: Violence within the Church in Diocese of Cracow at the Beginning of 14th Century, w: Ecclesia et Violentia: Violence against the Church and Violence within the Church in the Middle Ages, red. R. Kotecki, J. Maciejewski, Newcastle upon Tyne 2014.

Maciejewski J., Memory of Militant Bishops of Płock in the Writings of John Dtugosz, w: Christianity and War in Medieval East Central Europe and Scandinavia, red. R. Kotecki, C. Selch Jensen, S. Bennett, Leeds 2021.

Maleczyński K., Studya nad dyplomami i kancelaria Odonica i Laskonogiego 1202-1239, Lwów 1928.

Matuszewski J., Immunitet ekonomiczny w dobrach kościoła w Polsce do 1381 roku, Poznań 1936.

Manthey J., Średniowieczne duszpasterstwo wojskowe, „Duszpasterz Polski Zagranicą” 1958, 9, 3.

Mika N., Udział ksiażąt ślaskich w wydarzeniach w Gasawie w 1227 roku, w: Gasawa w pamięci historycznej. W zwiazku z 620. rocznica lokacji miasta, red. D. Karczewski, Inowrocław 2009.

Mosingiewicz K., Choragwie rodowe i ich dowódcy w bitwie pod Grunwaldem, w: Prace z dziejów państwa i zakonu krzyżackiego, red. A. Czacharowski, Toruń 1984.

Nakashian C.M., Warrior Churchmen of Medieval England 1000-1250. Theory and Reality, Woodbridge 2016.

Nelson J., Politics and Ritual in Early Medieval Europe, London 1986.

Nemerkényi E., The Representation of the Bishops in the Institutio of King Stephen of Hungary, „Acta Classica Universitatis Scientiarum Debrecenensis" 2001, 37.

Niwiński M., Biskup krakowski Bodzanta i Kazimierz Wielki, "Collectanea Theologica” 1936, $17,1-2$.

Nowacki B., Czeskie roszczenia do korony w Polsce w latach 1290-1335, Poznań 1987.

Nowacki B., Przemyst II. Odnowiciel Korony Polskiej (1257-1296), Kraków 2017.

Nowak E., Rys dziejów duszpasterstwa wojskowego w Polsce 968-1831, Warszawa 1932.

Nowakowski T., Jan Długosz jako kronikarz dziejów piastowskiego Mazowsza (do początku $X V$ w.) w: Dziedzictwo ksiażąt mazowieckich. Stan badań i postulaty badawcze, red. J. Grabowski, R. Mroczek, P. Mrozowski, Warszawa 2017.

Ożóg K., Intelektualiści w stużbie Królestwa Polskiego w latach 1306-1382, Kraków 1995.

Pauk M.R., Wółkiewicz E., "Ministri enim altaris ministri curie facti sunt”. Ottońsko-salicki "system" Kościoła Rzeszy i jego oddziaływanie w Europie Środkowej XI-XII wieku, w: Kościót w monarchiach Przemyślidów i Piastów, red. J. Dobosz, Poznań 2009.

Paul M.C., Secular Power and the Archbishops of Novgorod Before the Muscovite Conquest, „Kritika: Explorations in Russian and Eurasian History" 2007, 8, 2.

Perron A., Saxo Grammaticus's Heroic Chastity: A Model of Clerical Celibacy and Masculinity in Medieval Scandinavia, w: Negotiating Clerical Identities. Priests, Monks and Masculinity in the Middle Ages, red. J.D. Thibodeaux, Genders and sexualities in history, Basingstoke-New York 2010.

Pietras T., "Krwawy wilk z pastorałem”. Biskup krakowski Jan zwany Muskata, Warszawa 2001.

Pintér J.Z., Tatárok és magyarok (1241-1242), „Hadtörténelmi Közlemények” 2005, 118, 3.

Ptak J., Co Jan Dtugosz mógł wiedzieć o bitwie rozegranej w 1205 roku pod Zawichostem?, w: Ecclesia - Cultura - Potestas. Studia z dziejów kultury i społeczeństwa, red. P. Kras et al., Kraków 2006.

Ptak J., Duszpasterstwo rycerstwa polskiego w epoce Piastów i Jagiellonów, w: Historia duszpasterstwa wojskowego na ziemiach polskich, red. J. Ziółek, Lublin 2004. 
Ptak J., Zanim wyruszyli na wroga... Religijne przygotowanie do walki zbrojnej w średniowiecznej Polsce, „Teka Komisji Historycznej. Oddział Lubelski PAN” 2014, 11.

Reilly F., The Kingdom of León-Castilla Under King Alfonso VII, 1126-1157, Philadelphia 1998.

Reuter T., "Episcopi cum militia sua”. The Prelate as Warrior in the Early Staufer Era, w: Warriors and Churchmen in the High Middle Ages. Essays presented to Karl Leyser, red. T. Reuter, London-Rio Grande 1992.

Reuter T., The "Imperial Church System" of the Ottonian and Salian Rulers: A Reconsideration, „Journal of Ecclesiastical History" 1982, 33, 3.

Russell F.H., The Just War in the Middle Ages, Cambridge 1975.

Rybarski A., Udział Toporczyków w uwięzieniu biskupa krakowskiego, „Kwartalnik Historyczny" 1912, 26.

Schild S., Bishops in the Service of the Staufen and the Plantagenets, w: Staufen and Plantagenets. The Empires in Comparision, red. A. Plassmann, D. Büschken, Bonn 2018.

Silnicki T., Arcybiskup Mikołaj Trąba, Warszawa 1954.

Słupecki L.P., Bitwa pod Zawichostem 19 czerwca 1205, w: Szkice zawichojskie, red. T. Dunin-Wąsowicz, S. Tabaczyński, Zawichost 1999.

Słupecki L.P., Bitwa pod Zawichostem, niedziela 19 czerwca 1205, w: Zawichost we wczesnym średniowieczu, red. S. Tabaczyński, D. Wyczółkowski, współpr. D. Cyngot, Warszawa 2018.

Smolka S., Mieszko Stary i jego wiek, Kraków 1881 (cyt. wyd. Kraków 2009).

Sot M., Des érêques á la guerre (VIII -XIII ciècle), w: Guerre et société (IXe-XIIIe siècle), red. J.-C. Chenyet, D. Barthelemy, Paris 2011.

Sójka J., Postugi duszpasterskie przy wojskach polskich w wiekach średnich, w: Studia z dziejów feudalizmu, red. S.M. Zajączkowski, Łódź 1994.

Spież J.A., Średniowieczne świadectwa życia i kultu błogosławionego Czesława, w: Dominikanie w środkowej Europie w XIII-XV wieku. Aktywność duszpasterska i kultura intelektualna, red. J. Kłoczowski, J.A. Spież, Poznań 2002.

Spurgjasz K., Modlitwy o zwycięstwo w kościołach polskich w 1443 roku, w: Wojna a religia w średniowieczu, red. M. Zapiór, Kraków 2009.

Sroka S., Z dziejów stosunków polsko-węgierskich w późnym średniowieczu: szkice, Kraków 1995.

Stöckel J.-P., Reichbischöfe und Reichheerfahrt unter Friedrich I. Barbarossa, w: Keiser Friedrich Barbarossa. Landesaubau - Aspekte seiner Politik - Wirkung, red. E. Engel, B. Töpfel, Weimar 1994.

Sułkowska-Kuraś I., Dokumenty królewskie i ich funkcja w państwie polskim za Andegawenów i pierwszych Jagiellonów, Warszawa 1977.

Sułkowska-Kuraś I., Polska kancelaria królewska w latach 1447-1506, Wrocław 1967.

Szybkowski S., Duchowni "panowie choragiewni" podczas letniej wyprawy na Prusy w 1410 r., w: Kościót i społeczeństwo. Studia nad obiegiem informacji i konfliktami zbrojnymi w dawnych i nowych wiekach, red. J. Grabowski, Warszawa 2012.

Śliwiński B., O charakterze zjazdu gąsawskiego i rzekomo mającej tam miejsce bitwie, „Studia z Dziejów Średniowiecza" 2015, 19.

Śliwiński B., Pomorze Wschodnie w okresie rząów księcia polskiego Władysława Łokietka w latach 1306-1309, Gdańsk 2003.

Taylor L., Bishops, War and Canon Law. The Military Activities of Prelates in High Medieval Norway, "Scandinavian Journal of History” 2019, https://doi.org/10.1080/03468755.2 019.1684356.

Tęgowski J., Kanclerz kujawski Jarosław Bogoria i jego stosunki z Galhardem de Carceribus, w: Personae, colligationes, facta, red. J. Bieniak et al., Toruń [1991]. 
Tomaszek M., Modlitwa i łzy bronią biskupa. Pasterze polskiego Kościoła a walka orężna w ujęciu Wincentego Kadtubka, „Roczniki Historyczne” 2005, 71.

Umiński J., Arcybiskup Wincenty z Niałka, następca Henryka, zw. Kietliczem, w: Księga pamiatkowa ku czci Władysława Abrahama, Lwów 1931.

Vetulani A., Przenikanie zasad powszechnego prawa kanonicznego i prawa rzymskiego do piastowskiej Polski, w: A. Vetulani, Z badan nad kultura prawnicza w Polsce piastowskiej, Wrocław 1976.

Winroth A., "Decretum Gratiani” and Eystein's „Canones Nidrosienses”, w: Archbishop Eystein as Legislator: The European Connection, red. T. Iversen, Trondheim 2011.

Wojciechowski L., Wyprawy tupieskie w stowiańszczyźnie zachodniej w X-XII w, „Roczniki Humanistyczne" 1983, 31, 2.

Wybranowski D., Przydatność źródet zachodniopomorskich z XII-XIII wieku w badaniach nad dziejami wojen i wojskowościa średniowiecza, w: Formuła - Archetyp - Konwencja w źródle historycznym, red. A. Górak, K. Skupieński, Lublin 2006.

Wyrozumski J., Kościót i społeczeństwo polskie w świetle bulli papieża Innocentego III, w: Człowiek w społeczeństwie średniowiecznym, red. R. Michałowski et al., Warszawa 1997.

Zajączkowski S., Polska a Zakon Krzyżacki w ostatnich latach Władysława Łokietka, Lwów 1929.

Zdanek M., "Zaginiona kronika dominikańska” z XIII wieku. Próba nowego spojrzenia, w: Fontes et historia. Prace dedykowane Antoniemu Gasiorowskiemu, red. T. Jurek, I. Skierska, Poznań 2007.

Žemlička J., Jindřich Zdík, Biskup, dyplomat, a organizator, w: Jindřich Zdík (1126-1150). Olomoucký biskup uprostřed Evropy, red. J. Hrbáčová, Olomouc 2009.

\section{NOTA O AUTORZE}

Jacek Maciejewski - prof. dr hab., kierownik Katedry Historii Średniowiecznej na Wydziale Historycznym Uniwersytetu Kazimierza Wielkiego w Bydgoszczy. Głównym obszarem badań prof. Maciejewskiego jest działalność wyższego duchowieństwa w średniowieczu, ze szczególnym uwzględnieniem polskiego episkopatu. Jest autorem trzech monografii, w tym: Episkopat polski doby dzielnicowej 1180-1320 (Societas Vistulana 2003) oraz Adventus episcopi (UKW 2013), redaktorem lub współredaktorem wielu tomów zbiorowych, w tym: Ecclesia et violentia (CSP 2014) oraz Between Sword and Prayer (Brill 2018), a także autorem wielu artykułów opublikowanych w czołowych polskich i zagranicznych czasopismach i wydawnictwach naukowych. 